\title{
SYSTEMATIC AFFINITIES OF THE EXTINCT METATHERIAN EOBRASILIA COUTOI SIMPSON, 1947, A SOUTH AMERICAN EARLY EOCENE STAGODONTIDAE: IMPLICATIONS FOR "EOBRASILIINAE"
}

\author{
LEONARDO M. CARNEIRO \& ÉDISON V. OLIVEIRA \\ Laboratório de Paleontologia (PALEOLAB), Departamento de Geologia, Centro de Tecnologia e Geociências, \\ Universidade Federal de Pernambuco. Av. Acadêmico Hélio Ramos s/n, 50740-530, Recife, PE, Brazil. \\ leonardo.carneiro8@gmail.com,vicenteedi@gmail.com
}

\begin{abstract}
Eobrasilia coutoi Simpson is currently considered one of the most enigmatic metatherian mammals of Itaboraí Basin, Brazil. A single badly broken and incomplete skull, with a single strongly worn M3, and an associated fragmentary dentary are the elements currently attributed to this taxon. This fragmentary condition contributes for its uncertain position within Metatheria. Herein, the preserved dental morphology of this species is re-analyzed. The morphology of these structures, such as a tiny, obliquely oriented, one-rooted P1; absence of retro-premolar spaces between the premolars and mesiodistally developed p3, supports the assignment of Eobrasilia as a South American stagodontid. This new result leads a systematic review of the affinities of "Eobrasiliinae", currently represented by Eobrasilia, Gaylordia and Didelphopsis. The hypothesis that "Eobrasiliinae" represents a valid taxon is refuted in the phylogenetic analysis, which recovered Eobrasilia as more closely related to Didelphodon within Stagodontidae, Gaylordia as the sister taxon of Tiulordia and more closely related to Minusculodelphis and Marmosopsis, and Didelphopsis as the sister taxon of Itaboraidelphys and more closely related to Herpetotherium, Carolopaulacoutoia and Derorhynchus. The shared characters between Eobrasilia, Gaylordia and Didelphopsis were likely a result of convergent evolution, as these three lineages independently adapted to more durophagous diets. The phylogenetic analysis did not support the sister relation between Fumodelphodon and Didelphodon and Eodelphis and Hoodootherium. The grouping of Eobrasilia and Didelphodon corroborates the previous hypothesis that Metatheria dispersed from North to South America during the Late Cretaceous.
\end{abstract}

Key words: Early Eocene, Eobrasilia, “Eobrasiliinae”, Itaboraí, Stagodontidae, systematics.

RESUMO - Eobrasilia coutoi Simpson é considerado atualmente como um dos metatérios mais enigmáticos da Bacia de Itaboraí, Brasil. Um crânio muito fragmentado e incompleto com um M3 muito desgastado, e um dentário fragmentado são os únicos elementos atribuídos a esse táxon. Essa "fragmentação" dos materiais associados ao gênero Eobrasilia contribui para a sua posição incerta dentro do clado dos Metatheria. Aqui, a morfologia dentária preservada dessa espécie é reanalisada. A presença de um P1 pequeno, com uma orientação oblíqua em relação aos P2-3 e com uma única raiz; ausência de espaços retro-premolares entre os pré-molares e o evidente desenvolvimento mesiodistal do p3 suportam a associação de Eobrasilia como um stagodontídeo sul-americano. Esse novo resultado levou a uma revisão sistemática das afinidades dos "Eobrasiliinae", previamente representado por Eobrasilia, Gaylordia e Didelphopsis. A hipótese de que "Eobrasiliinae" representa um táxon válido é refutada pela análise filogenética, que recuperou Eobrasilia como grupo-irmão de Didelphodon e pertencente à família Stagodontidae; Gaylordia como táxon irmão de Tiulordia, sendo ambos mais próximos filogeneticamente de Minusculodelphis e Marmosopsis; e Didelphopsis como grupo-irmão de Itaboraidelphys e esses aparentados filogeneticamente a Herpetotherium, Carolopaulacoutoia e Derorhynchus. Os caracteres compartilhados entre Eobrasilia, Gaylordia e Didelphopsis são resultado de evolução convergente, visto que essas três linhagens se adaptaram independentemente para dietas mais durófagas. A análise filogenética não suporta a relação de grupo-irmão entre Fumodelphodon e Didelphodon, e de Eodelphis com Hoodootherium. O agrupamento de Eobrasilia e Didelphodon corrobora a hipótese de que os metatérios se dispersaram da América do Norte para a América do Sul durante o Cretáceo Superior.

Palavras-chave: Eoceno Inferior, Eobrasilia, “Eobrasiliinae”, Itaboraí, Stagodontidae, sistemática.

\section{INTRODUCTION}

Eobrasilia coutoi Simpson, 1947, was discovered in fissure fillings of early Eocene Itaboraian South American Land Mammal Age (SALMA - ca 53-50 Ma; Woodburne et al., 2014) in the Itaboraí Formation at São José de Itaboraí Municipality, State of Rio de Janeiro, Brazil (Marshall, 1984). Represented by a badly broken and incomplete skull with heavily worn teeth (Simpson, 1947), and by a fragmentary dentary (Marshall, 1984), Eobrasilia received little attention since its formal description, being traditionally identified as a potential "missing-link" between Borhyaenoidea and "Didelphoidea" metatherians (sensu Simpson, 1947), and as a Didelphidae (sensu Paula Couto, 1962), though its position among "Didelphoidea" was supported by Marshall (1984).

The presence of large and inflated premolars, especially the p3, led Eobrasilia to be grouped by Marshall (1987) with Didelphopsis Paula Couto, 1952, Tiulordia Marshall \& Muizon, 1988, and Gaylordia Paula Couto, 1952, into the subfamily Eobrasiliinae, within Didelphidae. Besides this feature, no other study has found diagnostic characters that support these taxa as constituting a monophyletic group. 
A revision of petrosal and dental materials from Itaboraí placed Eobrasilia as more closely related to Didelphodon Marsh, 1889 than to Didelphopsis and Gaylordia (see Ladevèze \& Muizon, 2010). Oliveira \& Goin (2011) and Oliveira et al. (2016) considered Gaylordia as closely related to Minusculodelphis and Marmosopsis. Oliveira \& Goin (2015) thought of Gaylordia as closely related to Pucadelphyidae and Peradectidae, but did not include a jaskhadelphyid or a closely related taxon in their analysis. Goin (2003) suggested the inclusion of Didelphopsis, Itaboraidelphys and Carolopaulacoutoia in the family "Sternbergiidae" (McKenna \& Bell, 1997); but this result was not supported by Oliveira \& Goin (2011), and Oliveira et al. (2016), that considered Didelphopsis as closely related to Itaboraidelphys as the sister lineage of Carolopaulacoutoia, Peratherium, Derorhynchus and Djarthia, refuting the validity of "Sternbergiidae". The validity of "Eobrasiliinae" was previously contested by Oliveira \& Goin (2012) based on the fact that Didelphopsis, Gaylordia and Eobrasilia do not constitute a monophyletic lineage, as commented. For Oliveira \& Goin (2012), the evolution of massive premolars was a result of convergent evolution. The same study also called attention to the morphology of the incisors present in Eobrasilia.

Marshall (1984) tentatively assigned the MCT 2830-M, the type of Zeusdelphys complicatus Marshall, 1987 (a single and isolated M1), as the upper molar of Eobrasilia. However, this occlusal relation has never been studied in detail due to the absence of preserved lower molars of Eobrasilia. In the same study, Marshall (1984) commented about the great number of similarities between Eobrasilia and Stagodontidae Marsh, 1889. The similarities between these two lineages were also previously mentioned by Simpson (1947) (for him Thlaeodontinae, p. 7) and Ladevèze \& Muizon (2010).

The Stagodontidae is currently considered as a North American Late Cretaceous endemic family (Clemens, 1966; Fox \& Naylor, 1986, 2006; Lofgren, 1992; Eaton, 1993a, 2013; Cifelli, 2004; Williamson et al., 2012, 2014; Scott \& Fox, 2015). Currently represented by Eodelphis Matthew, 1916, Didelphodon, Hoodootherium Cohen, 2017, and Fumodelphodon Cohen, 2017, this lineage is characterized by the presence of inflated premolars, stout dentary, large size and lower molars with an enlarged paraconid (Clemens, 1966; Fox, 1981; Cohen, 2017). Pariadens is an enigmatic taxon with possible stagodontid affinities, following previous studies (Cifelli \& Eaton, 1987; Cifelli, 2004; Eaton, 1993a; Williamson et al., 2012, 2014; Wilson et al., 2016). Pariadens is known from the Cenomanian, representing one of the oldest metatherians of North America (Cifelli \& Eaton, 1987; Cifelli, 2004; Eaton, 1993a; Williamson et al., 2012, 2014). The oldest confirmed record of a stagodontid is the Smoky Hollow Member of the Straight Cliffs Formation (Turonian), southern Utah, with Hoodootherium and Fumodelphodon (Cohen, 2017). The presence of a stagodontid in the Smoky Hollow Member of the Straight Cliffs Formation (Turonian) was firstly proposed by Cifelli (1990). The Stagodontidae represents a unique and rare lineage in North America (Scott \& Fox,
2015), being evidently different from other Late Cretaceous taxa. As mentioned, previous studies commented about the similarities between Eobrasilia and this family (Simpson, 1947; Marshall, 1984; Ladevèze \& Muizon, 2010), but none has ever tested this hypothesis so far.

Herein, it is presented a review of the diagnostic characters of "Eobrasiliinae" and a redescription of the preserved materials assigned to Eobrasilia.

Institutional abbreviations. AMNH, American Museum of Natural History, New York, USA; DGM, Divisão de Geologia e Mineralogia, Rio de Janeiro, Brazil; MCT (ex DGM), Museu de Ciências da Terra, Rio de Janeiro, Brazil; MNHN Vil, Institut de Paléontologie, Múseum National d'Histoire Naturelle, Paris, França; MN, Museu Nacional, Rio de Janeiro, Brazil; QMF, Queensland Museum, Australia; TMP, Royal Tyrrell Museum of Palaeontology, Drumheller, Alberta, Canada; UCM, University of Colorado Museum, Colorado, USA; UCMP, University of California Museum of Paleontology, Montana, USA; ZMNH, Zhejiang Museum of Natural History, Hangzhou, Zhejiang Province, China.

Other abbreviations. $\mathbf{i}$, lower incisors with the numbers corresponding to its positioning; $\mathbf{m}$, lower molars; $\mathbf{M}$, upper molars; $\mathbf{p}$, lower premolars; $\mathbf{P}$, upper premolars.

\section{MATERIAL AND METHODS}

The matrix is based mainly on dental characters from the upper and lower dentition of fossil and living metatherians presented in Carneiro (2017 and references therein), but it also includes cranial, dentary and postcranial characters from Ladevèze \& Muizon (2010), Forasiepi et al. (2014), Wilson et al. (2016) and Beck (2017). The codification of the morphological matrix followed Carneiro (2017).

The Brazilian taxa were directly examined (i.e. fossil specimens and casts). In addition, literature descriptions, casts, digital and Scanning Electron Microscope (SEM) pictures were also analyzed. The Brazilian studied taxa come from the Itaboraí fossil locality in southeastern Brazil (Figure 1). The North American stagodontids were studied based on literature digital and SEM pictures, and original descriptions. The materials from Naturita (formerly Dakota) Formation (upper Cenomanian - Carpenter, 2014) were examined by casts and pictures. These casts were sent by Richard L. Cifelli and Joshua E. Cohen from the Oklahoma Museum of Natural History, OK, USA. The list of casts is given in the supplementary material.

The SEM pictures of DGM 919-M was made with the Scanning Electron Microscope JEOL JSM-6390LV at the Centro de Microscopia Eletrônica de Varredura do Departamento de Invertebrados do Museu Nacional, Museu Nacional, Rio de Janeiro, Brazil.

The analysis was conducted using a traditional search with TNT 1.1 (Goloboff et al., 2008) with 1000 replications and 1000 random seeds, saving 10 trees for replication. The morphological matrix is available as a supplementary material. Bremer supports and tree scores were calculated with TNT 1.1. The phylogeny presents 584 unordered characters, 


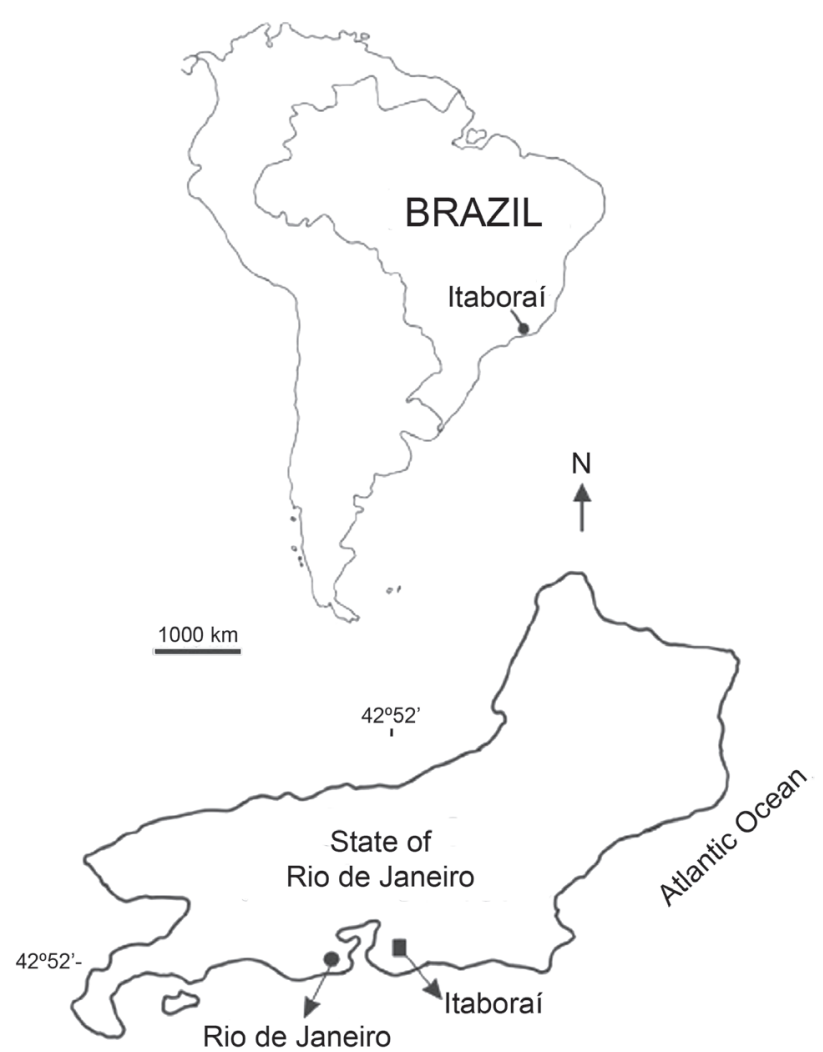

Figure 1. Location map showing the region and coordinates of the Itaboraí Basin, São José de Itaboraí, Rio de Janeiro, Brazil (22045'9.9144"S, 4251'53.5536"W).

including cranial, dentary, dental and postcranial characters, and 123 therian taxa, including more than 100 metatherians, from the Cretaceous and Cenozoic of North America, Asia and Gondwana.

The best way to test the validity of a character or to establish the affinities of a taxon is through a phylogenetic analysis (Simões et al., 2017). This study is based on the results of the phylogenetic analysis, as a priori systematic and taxonomical conclusions are not accepted as valid evidence in a systematic study without a phylogenetic analysis supporting it.

\section{SYSTEMATIC PALEONTOLOGY}

$$
\text { Class MAMMALIA Linnaeus, } 1758
$$

Infraclass METATHERIA Huxley, 1880

Supercohort MARSUPIALIFORMES Vullo et al., 2009

†Order ARCHIMETATHERIA Szalay, 1994

$\dagger$ Family STAGODONTIDAE Marsh, 1889

Emended diagnosis. Large, Late Cretaceous and Paleogene, North and South American metatherians in which trigonids are anteroposteriorly shortened, and paraconid and protoconid are of subequal height, and higher than the metaconid (modified from Clemens, 1966); first upper premolars are obliquely oriented and present well-developed anterior and posterior cusps; upper and lower premolars are closely spaced, with no evident retro-premolar spaces separating these teeth; lower incisors are semi-procumbent and not "staggered", third upper and lower premolars are inflated and the dentary is robust. Included genera. Hoodootherium, Fumodelphodon, Eodelphis, Didelphodon and Eobrasilia.

$\dagger$ Eobrasilia Simpson, 1947

1947 Eobrasilia Simpson, p. 2, figs. 2-4.

Type species. Eobrasilia coutoi Simpson, 1947.

Included species. The type only.

Occurrence. Itaboraí Basin and Formation, Municipality of Itaboraí, State of Rio de Janeiro, Brazil (Bergqvist et al., 2009). Early Eocene, Itaboraian SALMA (ca. 53-50 Ma; Woodburne et al., 2014).

\section{$\dagger$ Eobrasilia coutoi Simpson, 1947}

(Figure 2)

1947 Eobrasilia coutoi Simpson, p. 2, figs. 2-4.

1984 Eobrasilia coutoi Marshall, p. 174, figs. 1-2.

1987 Eobrasilia coutoi Marshall, p. 100, figs. 10-11.

Emended diagnosis. Differs from other Metatheria in the following combination of characters: two large semiprocumbent lower incisors (i1 and i3); massive and incipiently three-rooted $\mathrm{p} 3$ that is much larger than $\mathrm{p} 2$, inflated and deep dentary below $\mathrm{p} 3$, and narrow and markedly curved anterior part of the dentary.

Holotype. AMNH 39424, incomplete facial part of skull, with right $\mathrm{P} 1-3$, left $\mathrm{P} 3$ and $\mathrm{M} 3$.

Hypodigm. The type and DGM 919-M, a fragment of a right dentary with alveoli of incisors, canine and $\mathrm{p} 1$; complete $\mathrm{p} 2-3$ and anterior part of $\mathrm{m} 1$.

Occurrence. As for the genus.

Remarks. Eobrasilia can be securely identified as a metatherian due to the presence of three premolars and four molars (Simpson, 1947; Paula Couto, 1962; Marshall, 1984, 1987). The dental formula of Eobrasilia differs from the one of eutherians, which presents four premolars and three molars. The idea that Eobrasilia may represent another mammalian lineage than Metatheria presents no reliable evidence based on current fossil record.

When compared to most of the Late Cretaceous and Paleogene metatherians, Eobrasilia coutoi is closely related to Didelphodon from the Late Cretaceous of North America by the massive size of $\mathrm{p} 3$ with an evident mesio-distal elongation and one-rooted P1.

\section{PHYLOGENETIC ANALYSIS}

The analysis found four most parsimonious trees (trees scores $=2045 ; \mathrm{CI}=0.3400 ; \mathrm{HI}=0.6600 ; \mathrm{RI}=0.6580$ ) (Figure 3 ). Following the results, Eobrasilia is more closely related to Didelphodon within Stagodontidae. This result does not 
support proposals of Simpson (1947), Paula Couto (1962), Marshall $(1984,1987)$ or Marshall et al. (1990), who assigned this taxon to Didelphidae; however, supports Ladevèze \& Muizon (2010).

The association between Eobrasilia and Zeusdelphys as a single taxon (Marshall, 1984) was not supported as the last taxon does not show any of upper dentition synapomorphies of the Stagodontidae, and was recovered as the sister taxon of Hatcheritherium alpha Case, Goin \& Woodburne, 2005, within Hatcheriformes. Similar affinities for Zeusdelphys were found by Carneiro \& Oliveira (2017) and Carneiro (2017). This hypothesis, proposed by Marshall (1984), will be commented in detail later.

Pariadens was recovered as closely related to stagodontid, following Cifelli \& Eaton (1987), Cifelli (2004), Eaton (1993a), Williamson et al. (2012), and Wilson et al. (2016), who supported the affinities of this taxon with Stagodontidae. The results refute Fox \& Naylor (2006) and Williamson et al. (2014), who considered this taxon as not closely related to Stagodontidae.

The Turonian stagodontids Hoodootherium and

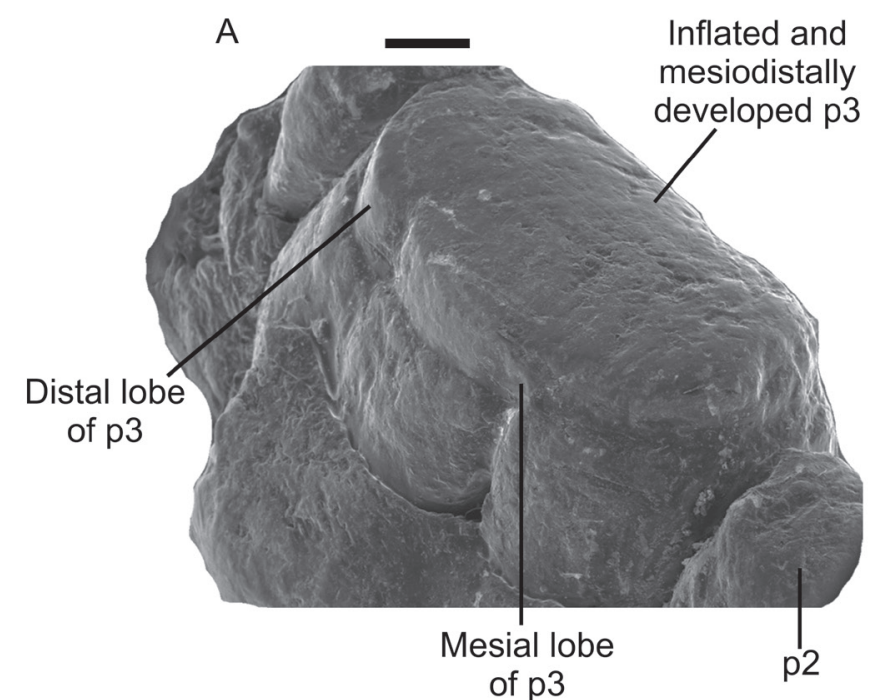

C

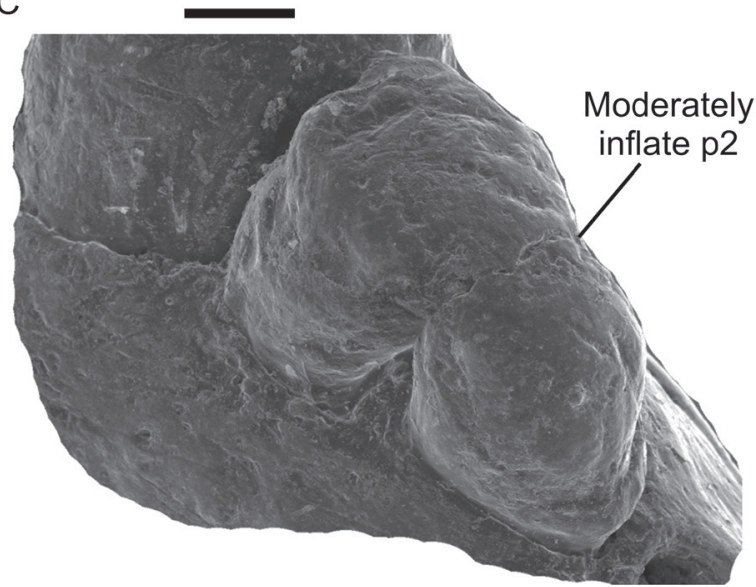

Fumodelphodon are the sister taxa of Eodelphis and (Eobrasilia + Didelphodon). This result does not support Cohen (2017), who considered Hoodootherium as the sister taxon of Eodelphis and Fumodelphodon as the sister taxon of Didelphodon.

The validity of "Eobrasiliinae" was not supported in the analysis, as Gaylordia + Tiulordia constitutes a monophyletic lineage more closely related to Jaskhadelphyidae Muizon, 1992. Didelphopsis cabrerai is more closely related to Itaboraidelphys camposi Marshall \& Muizon, 1984, both are the sister taxon of Herpetotherium Cope, 1873, Derorhynchus Paula Couto, 1952, and Carolopaulacoutoia (McKenna \& Bell, 1997); and Eobrasilia is closely related to Didelphodon.

The close relation of Pediomyoidea + Stagodontidae supports the validity of Archimetatheria proposed by Szalay (1994) (Figure 3). The Marsupialiformes and Deltatheroida are recovered in the analysis as sister taxa. The Pappotheriidae is the sister taxon of the clade that comprehends Marsupialiformes and Deltatheroida. These three lineages represent the mammalian Inflaclass Metatheria (see Figure 3).
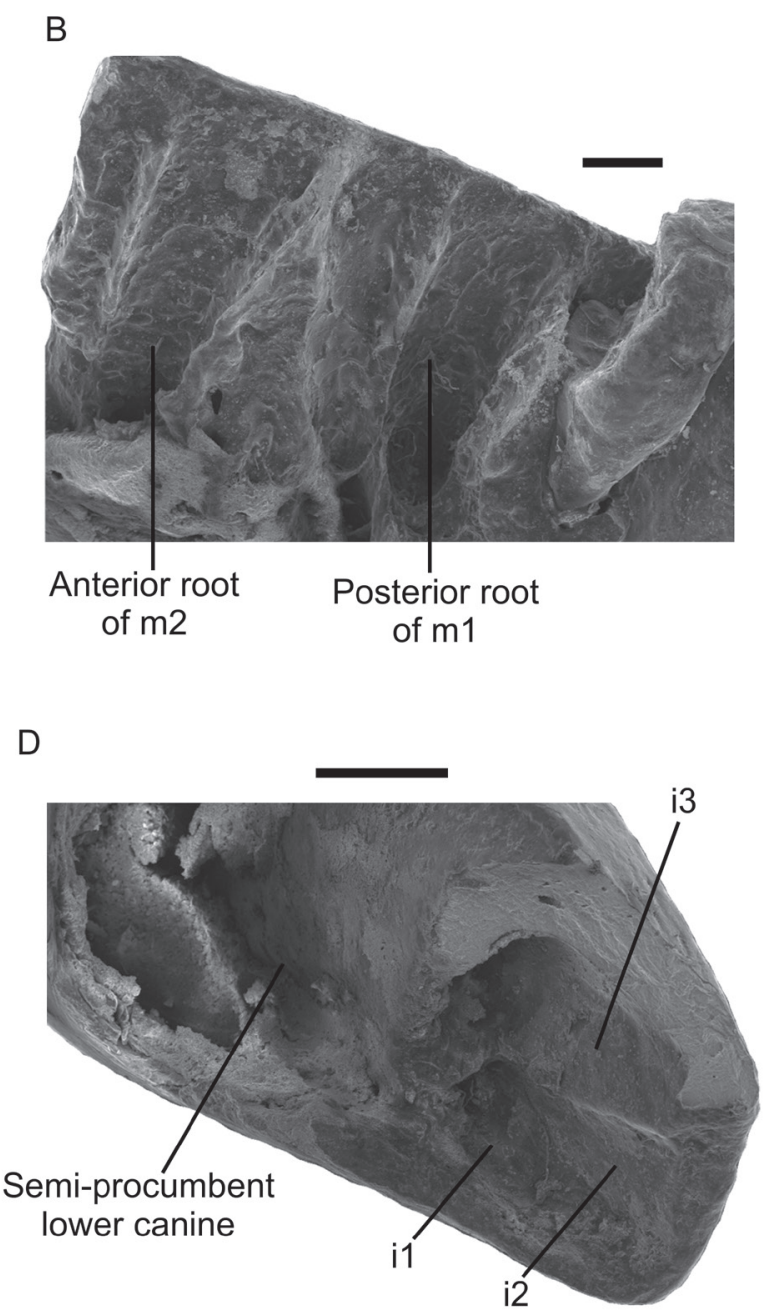

Figure 2. SEM photographies of the preserved dentary of Eobrasilia (DGM 919-M). A, p3 in antero-lingual view; B, alveoli of $\mathrm{m} 1 \mathrm{roots}$, with partially preserved paraconid of the right $\mathrm{m} 1$, and alveoli of $\mathrm{m} 2$ anterior root; $\mathbf{C}, \mathrm{p} 2$ in antero-lingual view showing the lingual flexid; $\mathbf{D}$, incisors and canine alveoli. Scale bars $=1 \mathrm{~mm}$. 


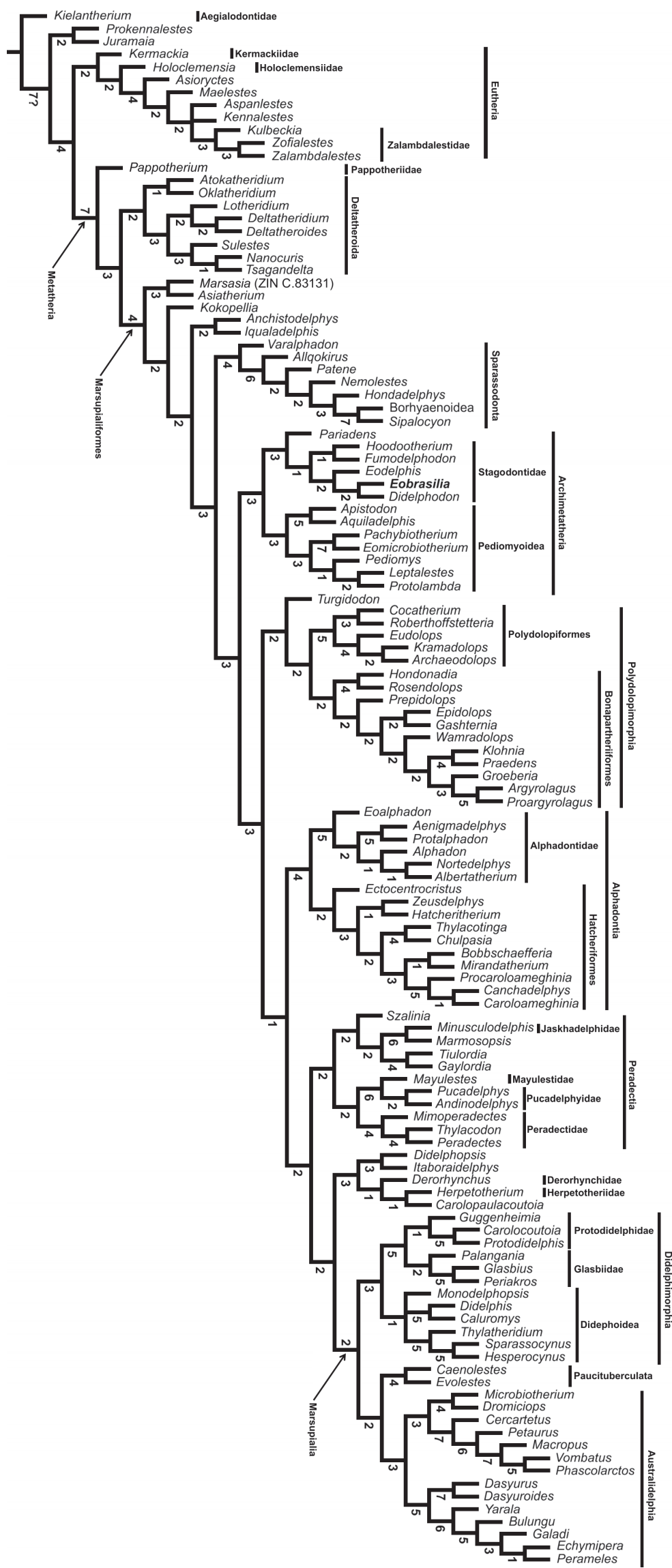

Figure 3. Result of phylogenetic analysis. Strict consensus tree of the four most parsimonious trees found in the analysis. The metatherian lineages are identified by vertical bars. Numbers below the branches indicate the Bremer Support. 


\section{DENTAL HOMOLOGIES}

\section{Morphology of first premolar}

The presence of a single-rooted P1 was identified in Didelphodon vorax and Eobrasilia coutoi (Figure 4). A preserved maxilla assigned to Eodelphis browni presents a two-rooted P1 (Fox \& Naylor, 2006), unlike Didelphodon vorax (Lofgren, 1992) and Eobrasilia coutoi (Marshall, 1984, 1987) (Figure 4). Other North and South American taxa such Pucadelphys, Herpetotherium, Didelphopsis, Sparassodonta, Roberthoffstetteria, Mimoperadectes, Szalinia, Gaylordia macrocynodonta, and almost all South American Marsupialia Illiger, 1811, also present a two-rooted P1.

Some Deltatheroida (e.g. Lotheridium) and Australidelphia also present a single-rooted P1. The similar condition between Eobrasilia + Didelphodon, Australidelphia and Deltatheroida is recovered in the phylogenetic analysis as result of independent origins (i.e. convergent evolution). Following the analysis, this condition shows a significant level of homoplasy among Metatheria; nevertheless, the one-rooted P1 was recovered by the analysis as valid evidence for the grouping of Eobrasilia + Didelphodon.

The P1 of Stagodontidae is minute when compared to P2 or P3 and is obliquely orientated with respect to the dental row axis. Eodelphis, Didelphodon, Eobrasilia, Didelphopsis and Lotheridium show that the anterior root of this tooth is labially oriented, while the posterior root is lingually oriented (i.e. the anterior root is oriented to the external border of the maxilla - labial; while the posterior one is oriented to the internal buccal space - lingual) (Figure 4). The minute P1 of Eobrasilia, Eodelphis and Didelphodon are in contact with the canine and P2, a condition absent in Gaylordia, Didelphopsis and Lotheridium, as the P1 is evidently separated from P2 (i.e. these teeth are not in contact, Figures 5, 6).

The P1 of Eobrasilia presents two accessory cusps anteriorly and posteriorly placed to its main cusp (see Simpson, 1947); morphology also found in Eodelphis and Didelphodon (Figure 4). These cusps are developed and visible even in worn teeth. The P1 of Didelphopsis (Paula Couto, 1962), Gaylordia (Oliveira \& Goin, 2015), Szalinia (Muizon \& Cifelli, 2001), Herpetotherium (Fox, 1983), Acyon (Forasiepi et al., 2006), Roberthoffstetteria (Muizon, 1992) and Lotheridium (Bi et al., 2015) do not present developed anterior and posterior cusps. Similar accessory cusps are also present on the upper premolars of Didelphidae and Sparassocynidae (Reig et al., 1987); however, the phylogenetic analysis did not recover these morphologies as homologous (228:1).

A partially preserved maxilla of Didelphopsis cabrerai (MN 2884-V) presents a minute, obliquely placed and tworooted P1, with a better developed P2 and a much larger P3 (based on preserved alveoli) (Figure 5). The P1 of D. cabrerai is separated from P2 by a developed and visible space between P1 and P2 (these spaces between the premolars are identified in this study as retro-premolar spaces), which differs from the characteristic pattern present in Stagodontidae (Figures 4, 5). The partially preserved skull of Gaylordia macrocynodonta (DGM 329-M) also presents a minute and two-rooted P1, but differs from Didelphopsis and Stagodontidae, in having the P1 aligned in the same axis as the P2 and P3. The P1 of Gaylordia shows a similar morphology to the P1 of Didelphopsis, as both present a developed retro-premolar space separating P1 and P2 (Figure 5).

The Tiupampian Roberthoffstetteria nationalgeographica presents a better developed P3 compared to P1-2, a premolar series with all premolars closely spaced and nearly in contact, and an slightly oblique oriented P1 (Muizon, 1992). However, this species differs from Stagodontidae in the relatively larger size of P1 and relatively lesser inflation and development of the P3 (Figure 6). This taxon was recovered as closely related to Polydolopidae (Goin et al., 2003; Chornogubsky \& Goin, 2015).

Malleodectes mirabilis Arena et al., 2011, presents a reduced P1 comparing to P2-3 as in referred South and North American taxa (Arena et al., 2011; Archer et al., 2016). Nevertheless, the pattern of its upper premolars is divergent from the one present in American taxa. The P1 is two-rooted, poorly developed, but not as vestigial as in Stagodontidae, aligned with dental row axis and separated by a small retropremolar space from P2 (Arena et al., 2011; Archer et al., 2016) (Figure 6). Its morphology is more similar to Gaylordia. Malleodectes represents an independent evolutionary event of its lineage in Australia, not directly linked to any South American taxa, including Gaylordia. This conclusion is supported by Archer et al. (2016), who described new materials assigned to this taxon, grouping it in the family Malleodectidae, within Dasyuromorpha Gill, 1872.

Despite the presence of an oblique oriented and singlerooted P1 in Lotheridium mengi (Bi et al., 2015), this taxon does not show any inflation of the premolars, present a visible retro-premolar space separating $\mathrm{P} 1$ from $\mathrm{P} 2$, and undoubtedly differs from Marsupialiformes based on its dental morphology. The P1 is relatively larger than the one of Stagodontidae, Gaylordia, Didelphopsis and Malleodectes (Figure 6).

The phylogenetic analysis demonstrated that a singlerooted, obliquely oriented and tiny $\mathrm{P} 1$, independently evolved several times in the evolution of Metatheria, probably as an adaptation to durophagous diet. Nevertheless, the stagodontids are the only metatherians that present a tiny P1, obliquely oriented, closely spaced to remaining premolars (with no developed retro-premolars space), with two accessory cusps, and associated with large, but not plagiaulacoid third premolars.

The phylogenetic analysis recovered the obliquely oriented, one-rooted, tiny and closely spaced P1 compressed between the canine and P2, as evidences for the grouping of Eobrasilia within Stagodontidae (229:1, 230:1, 231:1 and 232:1, respectively). The same result was recovered for the accessory cusps of P1 (228:1).

The p1 of Didelphodon, Eodelphis and Eobrasilia is two-rooted, as remaining metatherians (Scott \& Fox, 2015); however, these three taxa differ from other metatherians as they show the anterior root of p1 lingually positioned to the canine (Figure 7). Lotheridium shows an oblique p1, but the anterior root is labially positioned to the canine and the canine and $\mathrm{p} 1$ are not in contact, indicating a non-homologous 


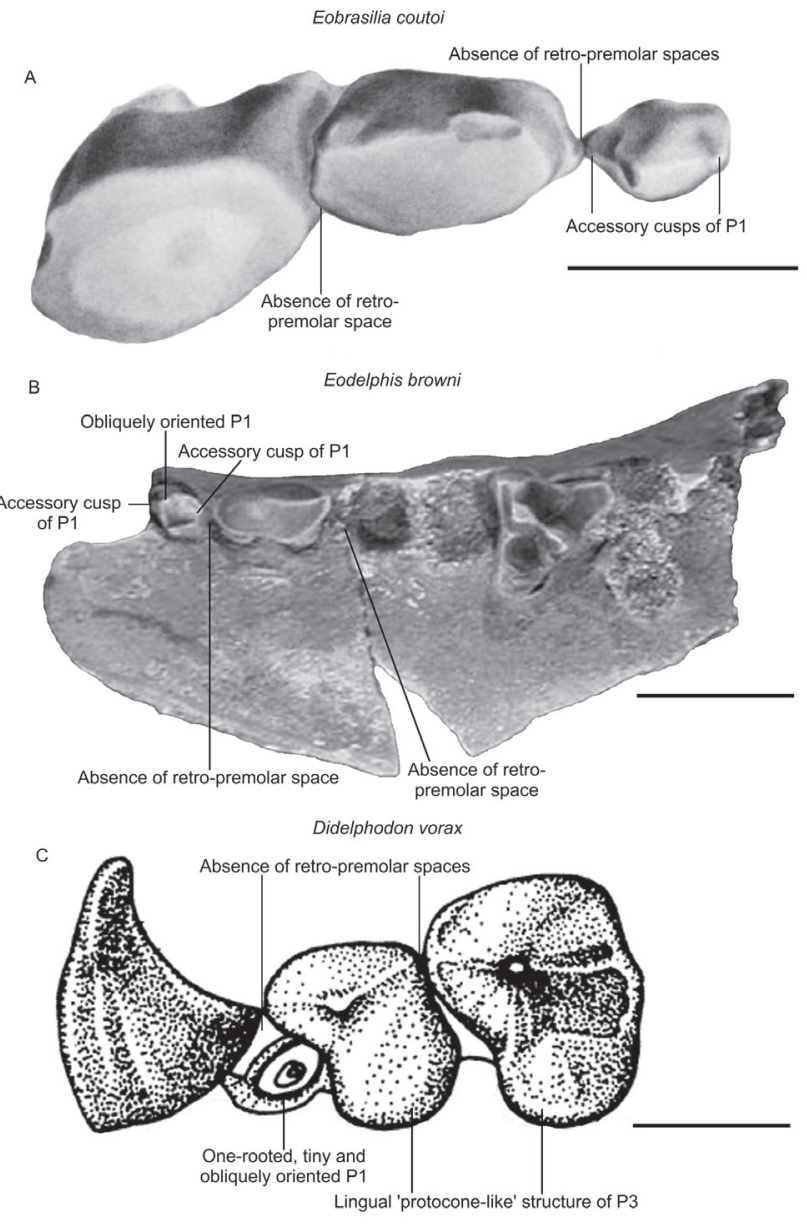

Figure 4. Upper premolars comparative morphology of Stagodontidae taxa. A, AMNH 39424 (type) of Eobrasilia coutoi, with right P1-3, adapted from Marshall (1984, p. 174, fig. 1); B, TMP 1985.053.0003, incomplete left maxilla of Eodelphis browni, with incomplete P1-2, M1 and alveoli for C, P3 and M2, adapted from Scott \& Fox (2015, p. 686, fig. 3); C, UCMP 134795, reconstruction of edentulous left maxilla fragment of Didelphodon vorax, adapted from Lofgren (1992, p. 163, fig. 1). Scale bars $=5 \mathrm{~mm}$.

condition to Stagodontidae. The lingual positioning of the anterior root of $\mathrm{p} 1$ to the canine can be considered as synapomorphy of Stagodontidae (233:1).

\section{Morphology of the second and third premolars}

The morphology of P2 and P3 in Eobrasilia, Didelphopsis, Eodelphis, Gaylordia, Didelphodon and Malleodectes are divergent for the condition present in remaining metatherians: the second and third premolars are very large and inflated, growing as large as or even larger than upper and lower molars (Figures 4-7). The presence of this pattern is an evidence for durophagous habits among these taxa (Fox \& Naylor, 2006; Arena et al., 2011; Scott \& Fox, 2015; Archer et al., 2016). Aside from this resemblance, these teeth present diagnostic morphologies that represent independent acquisitions for them.

Gaylordia presents a bulbous $\mathrm{P} 3$ that is much more massive than P2, but this pattern is not true for the lower dentition,
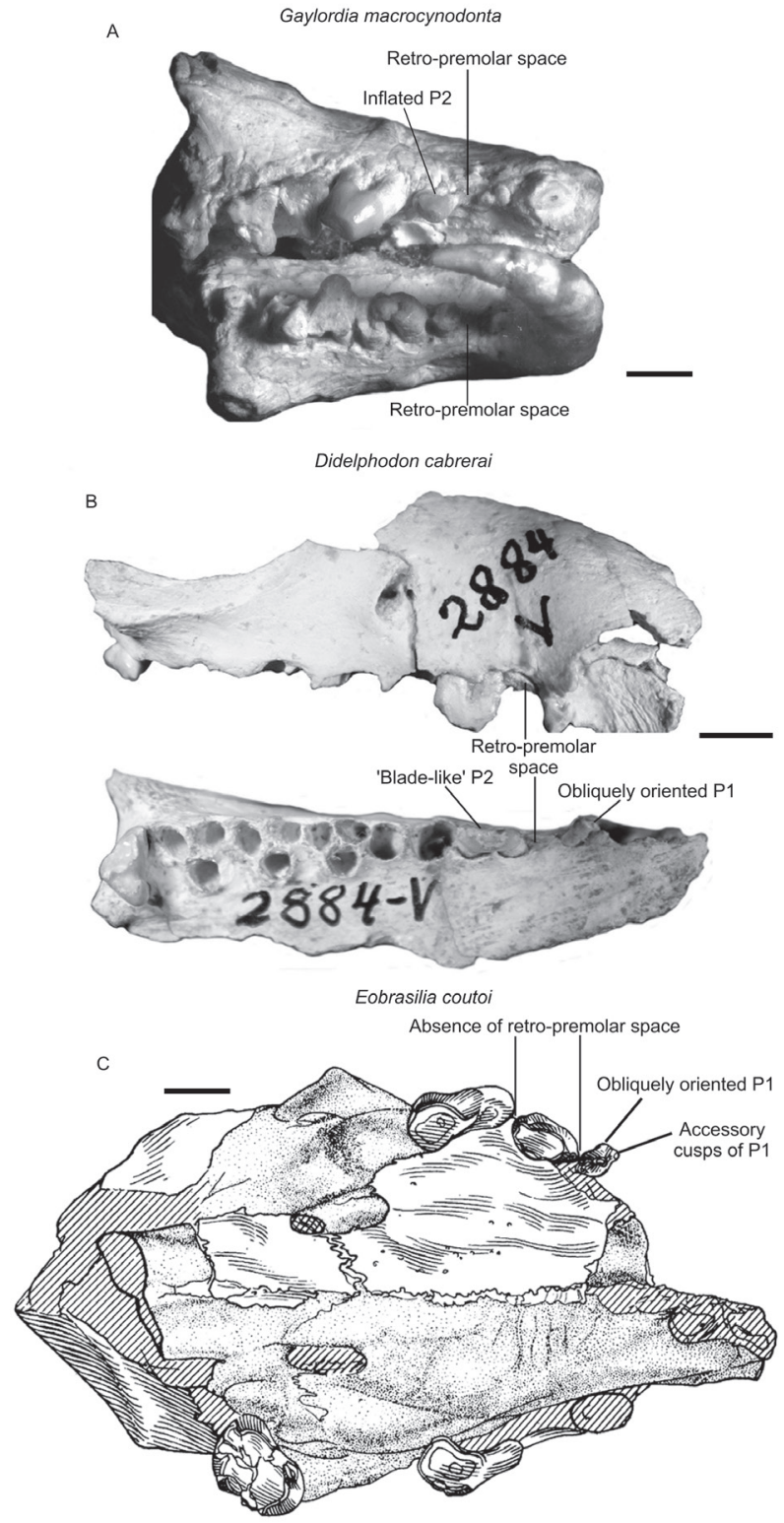

Figure 5. Comparative morphology of "Eobrasiliinae" upper premolars. A, DGM 329-M, partial skull of Gaylordia macrocynodonta in palatal view, adapted from Oliveira \& Goin (2015, p. 100, fig. 2); B, MN 2884-V, right maxilla of Didelphopsis cabrerai with preserved $\mathrm{p} 1$, p2 and $\mathrm{m} 4$ in labial (superior) and occlusal (below) views; C, AMNH 39424 , incomplete facial part of skull of Eobrasilia coutoi adapted from Simpson (1947, p. 5, fig. 2). Scale bars $=1 \mathrm{~mm}$.

as the second lower molar is only slightly less inflated and smaller than the third (Figure 8). In upper premolars, the P3 is inflated and rounded, but the P2 still retains a mesiodistal elongation and is not as inflated as the P3. The first premolars are evidently less developed and less inflated than the second premolars (Figure 5). This reduction in the size of $\mathrm{P} 1$ is not as evident as the one present in Eobrasilia,Didelphodon and Eodelphis, in which the first premolars are strikingly smaller than the second or the third premolars.

In Didelphopsis, the third premolars are strikingly larger and more inflated than the second premolars, which present a 

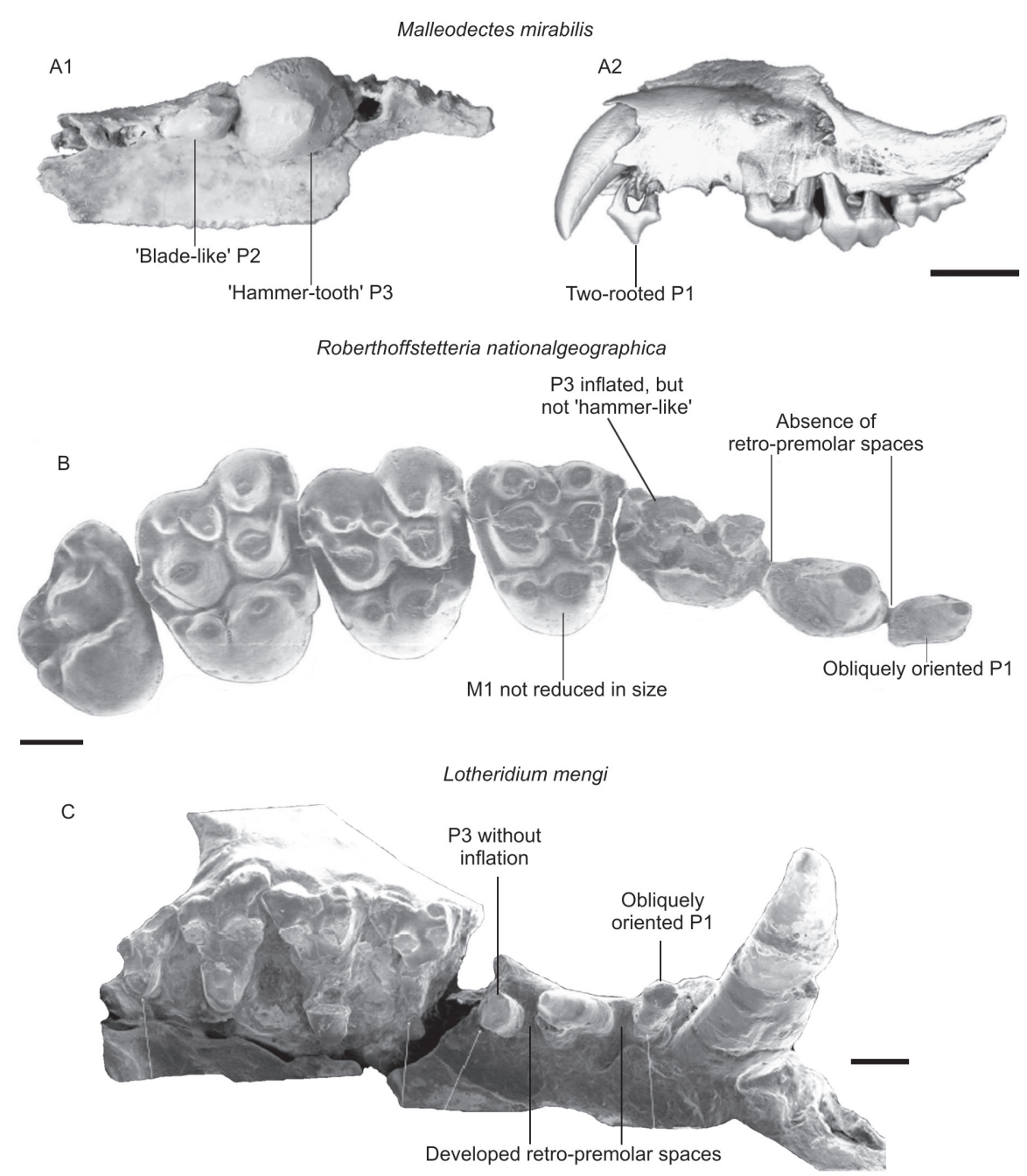

Figure 6. Upper premolars of Malleodectes, Roberthoffstetteria and Lotheridium. A1, QM F50847 (type), left maxillary fragment with P2-3 and alveoli of C-M2 of Malleodectes mirabilis, adapted from Archer et al. (2016, p. 4, fig. 4); A2, QM F57925, left maxilla with P1, DP3, M1-2 and alveoli of P2 of Malleodectes mirabilis, adapted from Archer et al. (2016, p. 4, fig. 4); B, MNHN Vil 99 (type), right maxilla with P1-M4 of Roberthoffstetteria nationalgeographica, adapted from Muizon (1992, p. 581, fig. 2); C, ZMNH M9032, upper canine, premolars and molars of Lotheridium mengi, adapted from Bi et al. (2015, p. 6, fig. 4). Abbreviations: M1, first upper molar; P1, first upper premolar; P2, second upper premolar; P3, third upper premolar. Scale bars: $\mathrm{A} 1-2=5 \mathrm{~mm} ; \mathrm{B}=1 \mathrm{~mm} ; \mathrm{C}=2 \mathrm{~mm}$.

more labiolingually compressed morphology and an incipient inflation. The second upper and lower premolars are more "blade-like" than the ones of Gaylordia (Oliveira \& Goin, 2015).

The Australian Malleodectes presents a poorly inflated P2 closely spaced to P3 (Arena et al., 2011; Archer et al., 2016). The $\mathrm{P} 3$ is rounded, massive and much more developed than the remaining teeth. This condition is quite similar to Gaylordia and Didelphopsis. These taxa present a "dome-like" P3 and a "blade-like" P2. Malleodectes differs from them in the presence of incipiently three-rooted P3 (Figure 6).

Eobrasilia resembles Eodelphis and Didelphodon in the larger size of the third premolars in comparison with the second ones (Figures 4,7). The inflation of second premolars in stagodontids varies from species to species: Eodelphis cutleri shows "blade-like" or slightly inflated second upper and lower premolars, which differs from E. browni that presents a slightly more inflated condition. Didelphodon coyi and $D$. vorax present an evident inflation of the second premolars. Among the species of Didelphodon, D. vorax shows the greatest degree of inflation of $\mathrm{p} 2$ in comparison with any other metatherian, an autapomorphy of this species. The p2 of Eobrasilia is twice the size of p1 (see Marshall, 1984), and is heavily worn. Judging by the size and outline, this tooth is more inflated than the one of Eodelphis browni, but less inflated than the one of Didelphodon.

The p3 of Eobrasilia and Didelphodon presents an evident mesio-distal elongation, a unique morphology among Metatheria (Figures 2, 7). Scott \& Fox (2015) describe this morphology as an autapomorphy of Didelphodon; however, the presence of a similar morphology in Eobrasilia was recovered by the analysis as a synapomorphy of Eobrasilia + Didelphodon (241:1). This character supports the assignment of Eobrasilia as a Stagodontidae. Eobrasilia differs from Didelphodon in the presence of an incipiently three-rooted condition. Marshall (1987) first identified this condition and 
it is confirmed in this study. This condition can be identified as an autapomorphy of Eobrasilia (see paleoecological implications of incipient three-rooted premolars).

Cohen (2017) recovered Fumodelphodon as the sister taxon of Didelphodon. However, the absence of a mesiodistally developed p3 in Fumodelphodon indicates that this taxon may represent an older divergent lineage than the one of Eobrasilia + Didelphodon (see the phylogenetic analysis in Figure 3). Eodelphis, Didelphodon and Eobrasilia show a developed distal lobe in third lower premolars, which is absent or incipiently developed in the $\mathrm{p} 3$ of Hoodootherium and Fumodelphodon. This distal lobe in third lower premolars is recovered as a shared synapomorphy (242:1) of Eodelphis and Didelphodon + Eobrasilia .

The presence of an incipiently three-rooted P3 in Malleodectes and Fumodelphodon, and in the $\mathrm{p} 3$ of Eobrasilia can be identified as an adaptation to the ingestion and crushing of harder food resources. Cohen (2017, p. 9) suggested the working hypothesis that the three-rooted condition in Fumodelphodon is morphologically and functionally antecedent to that of Didelphodon. Nevertheless, the phylogenetic analysis indicates that both morphologies represent independent adaptations to increase durophagy. The presence of an incipiently three-rooted p 3 in Eobrasilia, three-rooted P3 in Fumodelphodon and "the single, expanded distal root in Didelphodon" (Cohen, 2017, p. 9) indicates that the stagodontids developed independent morphologies to increase durophagous adaptations.

Didelphodon vorax and D. coyi show a lingual projection in P2 and P3. This morphology produces a "protocone-like" structure on the lingual border of the upper premolars in this genus (Figure 4), which probably is an adaptation to increase the crushing of hard food resources. The absence of upper premolars with preserved crowns of Eobrasilia does not allow the identification of a "protocone-like" cusp in third upper premolars of this taxon. Based on this, it is not possible to conclude if the presence of a "protocone-like" cusp in upper premolars is an ancestor adaptation of Eobrasilia + Didelphodon or an adaptation that evolved in Didelphodon. The Turonian Fumodelphodon shows a "protocone-like" cusp on the lingual border of P3, similar to Didelphodon; nevertheless, the phylogenetic analysis recovered this similar adaptation as result of homoplasy.

The inflated third and second lower premolars represent independent acquisitions for Tiulordia + Gaylordia, Didelphopsis and Stagodontidae (240:1), as indicated by the phylogeny (Figure 3). This conclusion is evident by the analysis of the condition present in most basal taxa of each grouping.

Tiulordia floresi and Gaylordia mater Oliveira \& Goin, 2015 , present an incipient inflation of $\mathrm{p} 3$, resulting in a tooth that is quite similar to the plesiomorphic condition of Metatheria (i.e. poorly inflated). In Gaylordia macrocynodonta the $\mathrm{p} 3$ and $\mathrm{p} 2$ are much more inflated and larger compared to the former, which represents an autapomorphy of this species. Gaylordia mater represents a mosaic condition between the basal Tiulordia and the specialized Gaylordia macrocynodonta (see Oliveira \& Goin, 2015).
The Stagodontidae presents a similar pattern, as Eodelphis, Hoodootherium and Fumodelphodon present less inflated premolars than Eobrasilia and Didelphodon (Figure 7). The result is the same for Didelphopsis cabrerai, which presents inflated and large third premolars and less inflated second premolars, again indicating an evolutionary tendency for the inflation of the last premolars.

\section{Closely spaced premolars and robust dentary}

The absence of retro-premolar spaces separating the lower premolars in the lower dentition and the robust dentary were considered by Marshall (1987) as strong evidences for the grouping of Eobrasilia, Gaylordia, Tiulordia, and Didelphopsis within "Eobrasiliinae". However, other taxa also lack these spaces between the premolars (e.g. Roberthoffstetteria nationalgeographica, Stagodontidae and some Borhyaenoidea). A robust dentary is also present in other metatherians, such as Pachybiotherium, Protolambda, Didelphodon and Roberthoffstetteria.

Interestingly, the presence of these characters is considered as adaptations to durophagy (e.g. Stagodontidae), granivory (e.g. Pachybiotherium), and carnivory (e.g. Sparassodonta) (see Zimicz, 2012), as the reduction in the length of dentary represents an adaptation to increase the bite force (Thomason, 1991).

Among Cretaceous North American taxa, the presence of a robust dentary, strong premolars, and an absence of retropremolar spaces in the upper and lower dentition represent diagnostic features of the Stagodontidae. Regarding South America, the conclusion is not similar as many lineages acquired some degree of durophagy. As previously mentioned the upper dentition of Stagodontidae shows a minute, obliquely placed, and strongly compressed $\mathrm{P} 1$, which is placed between the much larger canine and P2. These two premolars are also compressed to an even larger P3 (Figure 4). This absence of retro-premolar spaces between the upper premolars was recovered as an important character for Stagodontidae (232:1), excluding Tiulordia + Gaylordia and Didelphopsis from this lineage, and treating their similarities as result of independent acquisitions (see phylogeny and the previous topic).

The robust dentary and the strong wear pattern can be treated as important evidences for supporting durophagous feeding habits for Eobrasilia (see the paleoecology discussion), but these characters on their own could not be considered as strong phylogenetic evidence. Interestingly, the presence of these features in addition to the exclusive morphology and patterns present in the premolar series could be treated as compelling evidence for supporting stagodontid affinities for Eobrasilia.

The dentary of Eobrasilia shows evident labiolingual inflation around the $\mathrm{p} 3$ and its deepest point is below the p3; this morphology is probably a result of the enlarged condition of this tooth. These characters represent the main autapomorphies of Eobrasilia coutoi (Figure 7).

The dentary of Eobrasilia and Gaylordia macrocynodonta show an evident curvature of the anterior portion (Figures 7, 8). 


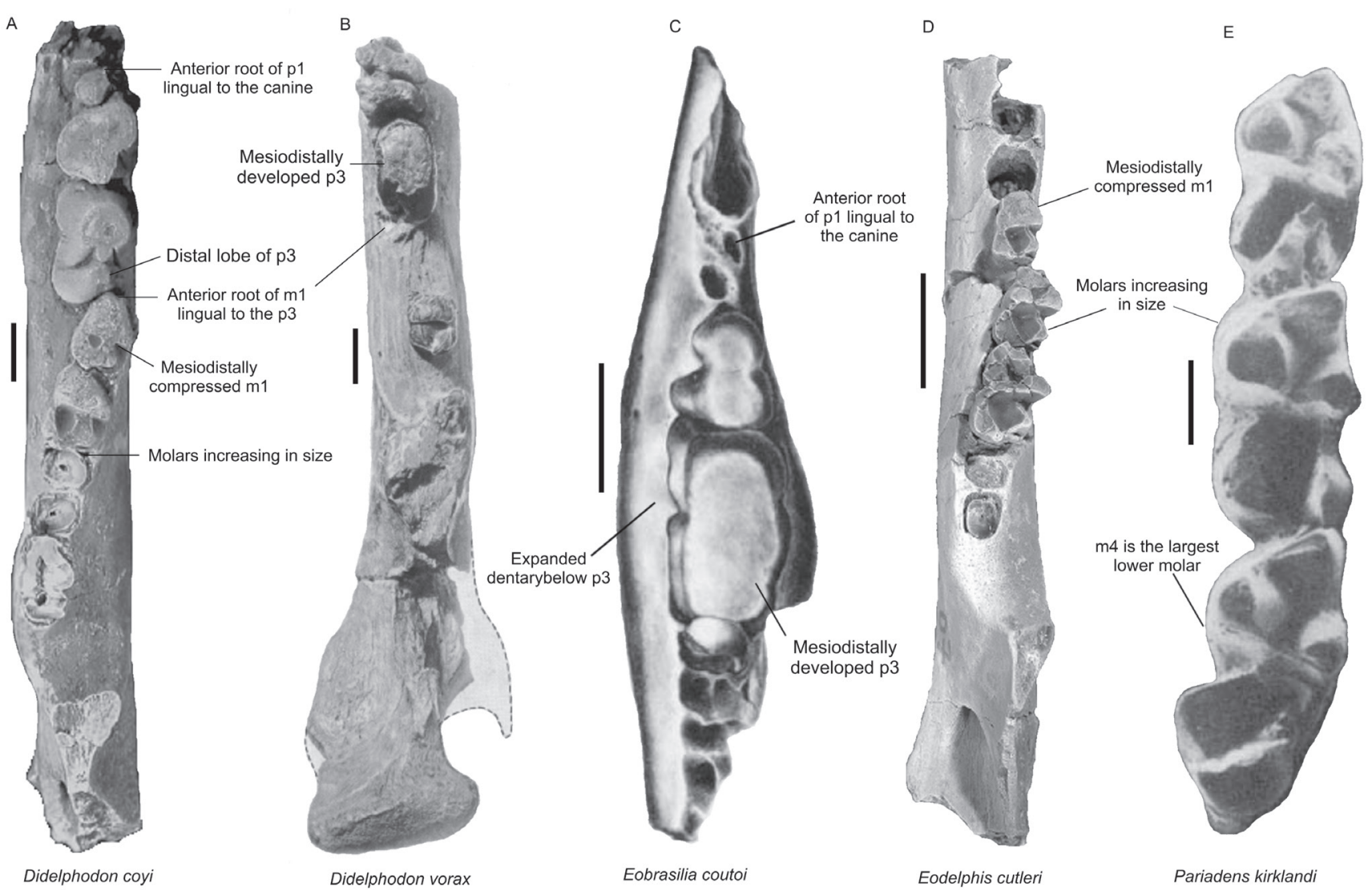

Figure 7. Comparative lower dental morphology of stagodontids. A, TMP 91.161.1, incomplete right dentary of Didelphodon coyi in occlusal view with p1-m2 and roots of $\mathrm{m} 3$ and $\mathrm{m} 4$, adapted from Fox \& Naylor (2006, p. 17, fig. 1); B, AMNH 3013, incomplete dentary of Didelphodon vorax with preserved p2, p3, m3 and posterior root of $\mathrm{m} 4$ in occlusal view, adapted from Matthew (1916, pl. 5, fig. 1); C, DGM 919-M, incomplete dentary of Eobrasilia coutoi with p2, p3, anterior root of $\mathrm{m} 1$ and alveoli for m2, p1, C and lower incisors, modified from Marshall (1964, p. 174, fig. 2); D, TMP 2002.012.0007, incomplete right dentary of Eodelphis sp., cf. E.cutleri with m1-3 and alveoli for p3 and m4 in occlusal view, adapted from Scott \& Fox (2015, p. 692, fig. 8); E, UCM 54155 (type), part of left mandibular ramus preserving the last three molars m2-4 of Pariadens kirklandi, adapted from Cifelli \& Eaton (1987, p. 521, fig. 1). Abbreviations: m1, first lower molar; p3, third lower premolar. Scale bars: $A-D=5 \mathrm{~mm}$; $E=1 \mathrm{~mm}$.

Marshall (1987) as evidence of their close relation considered this morphology. However, the phylogenetic analysis recovered this morphology as independent acquisitions for Gaylordia and Eobrasilia, constituting a convergent adaptation probably for more durophagous diets (258:1).

Eobrasilia differs from Eodelphis and Didelphodon by the strong curved condition of the anterior half of its dentary (Figure 8). Marshall (1987) compared the dentary of Eobrasilia with the one of Didelphopsis and Gaylordia: "The mandibular rami in Didelphopsis and Gaylordia are robust anteriorly, while in Eobrasilia the anterior part is narrow..." (Marshall, 1987, p. 133). A narrow anterior part of the dentary is also present in Eodelphis (Figure 8), but not as narrow and curved as in Eobrasilia.

Didelphodon coyi shows a curvature of the anterior part of the dentary similar to Eobrasilia; but they differ in the more robust constitution of this structure in Didelphodon. The dentary of Didelphodon is more similar to the one of Gaylordia and Didelphopsis in the more robust constitution and lesser degree of curvature comparing to Eobrasilia. Didelphodon is autapomorphic by the stronger compression of the anteriormost portion of the dentary, which strongly compressed the premolars, canine and incisors. The robust anterior part of the dentary is a convergent adaptation between Didelphopsis, Didelphodon and Gaylordia (Figure 8).

Based on the results of the phylogenetic analysis, the curvature of the dentary $(258: 1)$ and its robust constitution (259:1) represent independent acquisitions between Stagodontidae, Gaylordia, and Didelphopsis (Figure 3).

\section{Large size, mesiodistal compression of $\mathrm{m} 1$ and increasing in lower molar series}

Eobrasilia is considered as one of the largest metatherians from Itaboraí, being only slightly smaller than Zeusdelphys complicatus (based on upper or lower molars linear size). The large size of Eobrasilia and Zeusdelphys could indicate a compatible occlusal relation between the upper and lower teeth, as proposed by Marshall (1987). The type of Eobrasilia shows a strongly worn M3, not allowing details of its morphology. Direct comparisons could not be conducted as Eobrasilia presents a preserved M3, while Zeusdelphys presents a preserved M1 (Oliveira \& Goin, 2011). 


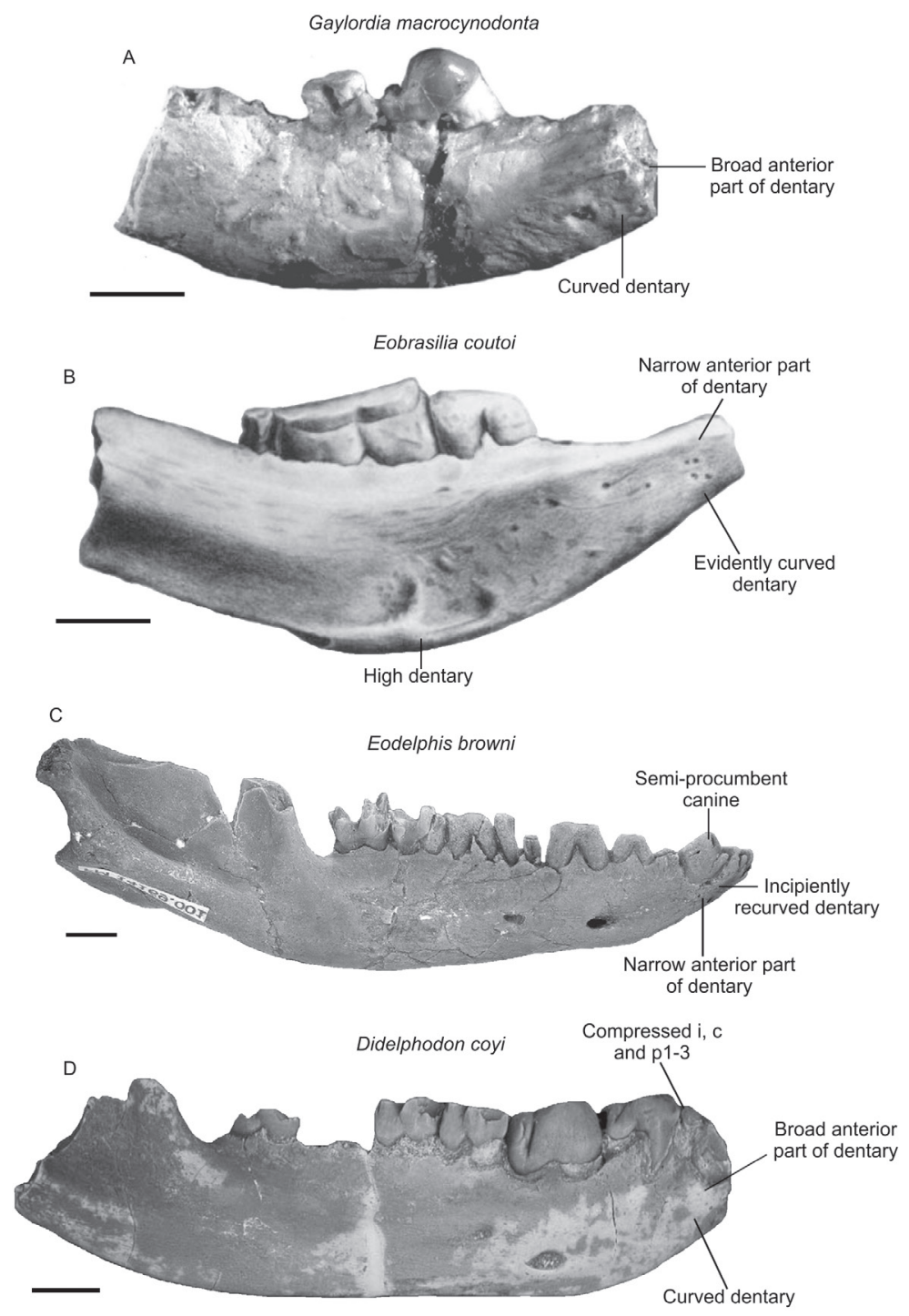

Figure 8. Comparative dentary morphology of "Eobrasiliinae" and Stagodontidae. A, DGM 329-M (type), incomplete dentary with p3 and worn m1 of Gaylordia macrocynodonta, adapted from Oliveira \& Goin (2015, p. 101, fig. 3); B, DGM 919-M, incomplete dentary of Eobrasilia coutoi with p2, p3, anterior root of $\mathrm{m} 1$ and alveoli for $\mathrm{m} 2, \mathrm{p} 1, \mathrm{C}$ and lower incisors, modified from Marshall (1964, p. 174, fig. 2); C, AMNH 14169, incomplete left dentary with i1-3, C, p1-3, m2-4 and roots of $\mathrm{m} 1$ of Eodelphis browni, adapted from Scott \& Fox (2015, p. 685, fig. 2); D, TMP 91.161.1, incomplete dentary with i2-3, C, p1-3, m1-4 of Didelphodon coyi, modified from Fox \& Naylor (2006, p. 21, fig. 2). Abbreviations: i, incisor; c, canine; p1, first lower premolar; p2, second lower premolar. Scales bars: A = $2 \mathrm{~mm}$; B-D = $5 \mathrm{~mm}$.

The M1 of Zeusdelphys cannot be considered as the M1 of Eobrasilia based on its relative size: this tooth reaches 8.30 $\mathrm{mm}$ in length and $8.47 \mathrm{~mm}$ in width (Oliveira \& Goin, 2011); this size is considerably larger than the one preserved in the alveoli of $\mathrm{m} 1$ of DGM 919-M (5.5 mm in length). The evident difference in size between the first molar of Zeusdelphys and Eobrasilia indicates that this occlusal relationship is not possible. In addition, Zeusdelphys does not present stagodontid upper molar synapomorphies, being recovered in the phylogenetic analysis as a hatcheriform, supporting Carneiro \& Oliveira (2017).

The $\mathrm{m} 1$ of Eobrasilia is smaller than the $\mathrm{m} 2$ (based on preserved alveoli) (Figure 2). Similar condition is also recognizable in the skull and dentary of Didelphodon vorax, which presents an M1 much smaller than M2 (Wilson et al., 2016), and a strongly mesiodistally compressed $\mathrm{m} 1$ (Matthew, 1916; Clemens, 1966). Didelphodon coyi shows a relatively lesser mesiodistal compression of m1 (Fox \& Naylor, 1986, 2006). The relative size between $\mathrm{m} 1$ and $\mathrm{m} 2$ in Eobrasilia is more similar to the one of Didelphodon coyi. The $\mathrm{m} 1$ of Eodelphis browni is slightly smaller than $\mathrm{m} 2$, but the one of E. cutleri is more mesiodistally compressed (Figure 7). Didelphodon is autapomorphic by the lingual positioning of the anterior root of $\mathrm{m} 1$ to $\mathrm{p} 3$ (Fox \& Naylor, 1986; Scott \& Fox, 2015).

The $\mathrm{m} 1$ is not known for the type specimen of Pariadens (UCM 54155); however, the specimen MNA V5842 found in Naturita Formation (upper Cenomanian, southwestern 
Utah, Carpenter, 2014) is smaller than remaining molars. Eaton (1993a), which indicates the presence of a smaller $\mathrm{m} 1$ than $\mathrm{m} 2, \mathrm{~m} 3$ or $\mathrm{m} 4$ in Pariadens identified this specimen as an $\mathrm{m} 1$. The Stagodontidae, presents the $\mathrm{m} 1$ as the smallest molar due to a mesio-distal compression, which was recovered as a synapomorphy of Stagodontidae (156:1). The m1 of Pariadens is smaller than remaining molars, but is not mesio-distally compressed, which supports its exclusion of Stagodontidae. Eaton (1993a) discussed the affinities of Pariadens and suggested that this taxon may be more appropriately placed in a new family.

The Stagodontidae shows an increase in size through the lower molar series, with the $\mathrm{m} 4$ being the largest tooth. Pariadens presents the same pattern. An m4 larger than m3 is also present in some Borhyaenoidea (Forasiepi et al., 2014), but the phylogenetic analysis recovered this adaptation as separate independent acquisitions. This character was recovered as a synapomorphy of Pariadens + Stagodontidae (224:1).

The stagodontids Eodelphis and Didelphodon were the largest metatherians during the Late Cretaceous in North America (Fox \& Naylor, 2006; Williamson et al., 2014; Scott \& Fox, 2015). Following the results, the larger size of Eobrasilia can also be considered as another evidence for its grouping within Stagodontidae. It is important to comment that the shared large size by its own could not be recovered as a strong systematic character (reason why this character is not include in the morphological matrix, as its use could result in a long and unnecessary discussion regarding this study). Nevertheless, the association of this feature with the results of the phylogenetic analysis endorses the grouping of Eobrasilia within Stagodontidae.

Gaylordia is considered one of the smallest species of Itaboraí, along with Minusculodelphis and Marmosopsis (Oliveira \& Goin, 2015; Oliveira et al., 2016). In fact, the smaller size seems to be an evolutionary tendency of this group. This evidence undoubtedly differs from the condition present in Eobrasilia, as it is one of the largest species of metatherians of Itaboraí. The difference in size could not be considered as a definitive evidence for the unrecognizing of "Eobrasiliinae" as a valid group, as commented, but this strong divergence in size associated with the commented characters can be considered as compelling evidence of the polyphyletic state of "Eobrasiliinae" (Table 1).

\section{Semi-procumbent lower incisors and canines}

Fox \& Naylor (2006) discussed the presence of semiprocumbent lower incisors in Didelphodon. Eodelphis present three unequally sized lower incisors, with the second (i2) much larger than i1 and i3. The presence of a staggered condition of i2 in Eodelphis is not clear, as it seems that the enlargement and "semi-procumbence" of i2 create this impression (Fox \& Naylor, 2006). In fact, the enlargement of lower incisors is also visible in Eobrasilia coutoi (Marshall, 1984) and Didelphodon coyi (Fox \& Naylor, 2006).

In the dentary of Eobrasilia (DGM 919-M) there are alveoli for three lower incisors (Figure 2). Marshall (1984) described Eobrasilia as presenting two large and inclined incisors, with one lying above the other. Marshall (1987) mentioned the presence of a small third incisor and a possible even smaller fourth incisor. The examination of DGM 919$\mathrm{M}$ founds no evidence of a fourth lower incisor alveolus. In fact, the two lingual most alveoli of i1 and i3 are easily identifiable, but the i2 is barely seen. As described by Marshall (1984) these teeth show, along with the canine, some degree of procumbence. In Eobrasilia the i2 is a compressed lower incisor, with its apparently "staggered" condition being a result of the extreme degree of procumbence of $i 1$ and $i 3$ that compressed the referred tooth in the middle, creating the false impression that it is "staggered". This hypothesis is confirmed by the study of the alveoli morphology of Didelphodon vorax that does not evidence any sign of a "staggered" lower incisor, as its incisors are equally sized and located at same level; this result agrees with Fox \& Naylor (2006).

Semi-procumbent lower incisors are absent in Pucadelphyidae, Peradectidae, Didelphidae, Marmosopsis, Sparassodonta, and Microbiotheriidae. Oliveira \& Goin (2012) proposed focused studies regarding the morphology of the incisors of Eobrasilia, Herpetotheriidae, and Protodidelphidae. The presence of two semi-procumbent incisors is reported for Herpetotherium fugax (Fox, 1983), but its condition is strikingly divergent from the one present in Stagodontidae, as Herpetotherium shows small and slightly procumbent i1, and i2 that are slightly larger and more procumbent than $\mathrm{i} 3$ and i4. In addition, Herpetotherium shows four alveoli, while Eobrasilia shows only three. Protodidelphidae does not show an evident procumbence of lower incisors, which diverge from the condition present in Eobrasilia.

The skull of Didelphodon vorax (see Wilson et al., 2016) presents semi-procumbent first incisors (I1), which are evidently better developed than the remaining ones (Figure 5). This morphology could not be recovered for Eobrasilia, as the type and only known skull does not preserve the upper incisors. Nevertheless, the presence of upper semiprocumbent incisors in $D$. vorax supports this morphology as a valid feature for Stagodontidae. The skull of Didelphodon and Eobrasilia share the presence of developed palatine foramina, differing in relative size. Eobrasilia presents less developed foramina than Didelphodon. The reduction of these foramina could be interpreted as an apomorphy of Eobrasilia based on the current fossil record.

The lower canines of Eodelphis browni and Eobrasilia coutoi are evidently semi-procumbent (Figures 2,8) and markedly larger in comparison with any of the living Didelphidae. Marshall (1984) described the canine of Eobrasilia as inclined anteriorly; a similar morphology is present in Eodelphis (Scott \& Fox, 2015). The canines of Didelphodon are less anteriorly procumbent, being more "erect".

In short, the morphology of the lower incisors and canines of Eobrasilia resemble the one present in North American stagodontids. The procumbence of lower incisors can be considered as an evolutionary tendency among this family, as all taxa show some degree of procumbence. The semi- 
Table 1. Premolars and dentary characters shared between Eobrasilia and other metatherians. The ' $\mathbf{X}$ ' indicates presence of the character; '?' indicates unknown condition for the character; and blank spaces indicate absence of the character. Eobrasilia shares few similarities with Gaylordia and Didelphopsis, while it shares almost all characters with Stagodontidae. These characters show a highly level of homoplasy, however, most of these features are shared only by Eobrasilia and Stagodontidae.

\begin{tabular}{|c|c|c|c|c|c|c|}
\hline Character/Taxon & Eobrasilia & Stagodontidae & Lotheridium & Didelphopsis & Gaylordia & Sparassodonta \\
\hline Accessory cusps in the P1 & $\mathrm{X}$ & $\mathrm{X}$ & & & & \\
\hline Single-rooted P1 & $\mathrm{X}$ & $\mathrm{X}$ & $\mathrm{X}$ & & & \\
\hline Oblique oriented P1 & $\mathrm{X}$ & $\mathrm{X}$ & $\mathrm{X}$ & $\mathrm{X}$ & & \\
\hline $\begin{array}{l}\text { Absence of retro-premolar space } \\
\text { between P1, P2 and P3 }\end{array}$ & $\mathrm{X}$ & $\mathrm{X}$ & & & & \\
\hline $\begin{array}{l}\text { Anterior root of } \mathrm{p} 1 \text { lingual to the } \\
\text { canine }\end{array}$ & $\mathrm{X}$ & $\mathrm{X}$ & & & & \\
\hline Mesio-distal development of p3 & $\mathrm{X}$ & $\mathrm{X}$ & & & & \\
\hline Mesio-distal compression of $\mathrm{m} 1$ & $\mathrm{X}$ & $\mathrm{X}$ & & & & \\
\hline Large size & $\mathrm{X}$ & $\mathrm{X}$ & & $\mathrm{X}$ & & $\mathrm{X}$ \\
\hline $\begin{array}{l}\text { Inflated and large third and/or second } \\
\text { premolars }\end{array}$ & $\mathrm{X}$ & $\mathrm{X}$ & & $\mathrm{X}$ & $\mathrm{X}$ & \\
\hline Semi-procumbent canines & $\mathrm{X}$ & $\mathrm{X}$ & & & & \\
\hline Semi-procumbent incisors & $\mathrm{X}$ & $\mathrm{X}$ & & & $?$ & \\
\hline Robust dentary & $\mathrm{X}$ & $\mathrm{X}$ & $\mathrm{X}$ & $\mathrm{X}$ & $\mathrm{X}$ & $\mathrm{X}$ \\
\hline Recurved dentary & $\mathrm{X}$ & & & & $\mathrm{X}$ & \\
\hline
\end{tabular}

procumbent lower incisors and canines, and the narrow dentary represent retained plesiomorphies for Stagodontidae. The semi-procumbence of lower incisors is not an evidence of herpetotheriid affinities for Eobrasilia based on the different pattern regarding the size, number and degree of semiprocumbence of the lower incisors.

\section{Systematic implications for Eobrasilia and "Eobrasiliinae"}

Eobrasilia shares several characters that are recovered as synapomorphies of Stagodontidae: anterior root of $\mathrm{p} 1$ lingual to the lower canine, mesiodistal development of the p3, semi-procumbent and enlarged lower incisors, mesiodistal compression of $\mathrm{m} 1$, absence of retro-premolar spaces in upper and lower dentition and accessory cusps in P1. Despite the absence of preserved molars of this species, the combination of characters supports the assignment of Eobrasilia as a Stagodontidae.

The hypothesis that Eobrasilia represents an "aberrant" lineage of South America is not supported in the analysis based on the following evidences: (i) the affinities of Eobrasilia were tested along with Eutheria, Pappotheriidae, Deltatheroida, Sparassodonta, Stagodontidae, Pediomyoidea, "Alphadontidae", Hatcheriformes, Polydolopimorphia, Peradectidae, Pucadelphyidae, Mayulestidae, Jaskhadelphyidae, Herpetotheriidae, Derorhynchidae, Didelphoidea, Protodidelphidae, Glasbiidae, Paucituberculata, Australidelphia, and several incertae sedis taxa. The phylogenetic analysis provides the largest morphological dataset ever published in literature; (ii) the great number of similar and unique adaptations between Eobrasilia and North American stagodontids is an important evidence, as no other metatherian lineage presents the anterior root of $\mathrm{p} 1$ lingual to the canine or the p 3 mesiodistally developed, for example; (iii) several previous studies proposed a North American origin for South American metatherians (discussed below), including Carneiro \& Oliveira (2017) and Carneiro (2017), who discussed the North American origin and dispersal of Hatcheriformes and Sparassodonta, respectively, to South America. Based on these studies, the presence of stagodontids in South America should not be discarded a priori.

The discovery of new specimens of Eobrasilia should help the discussion about the affinities of this taxon; nevertheless, the great number of shared synapomorphies and the absence of diagnostic traits of other metatherian lineages support, with some reliability, the assignment of Eobrasilia to Stagodontidae. Until the discovery of new specimens, the taxonomical hypothesis of stagodontid affinities for Eobrasilia represents the most parsimonious explanation.

The "Eobrasiliinae" is not supported, as it was erected based on convergent durophagous adaptations between three independent metatherian lineages: Gaylordia + Tiulordia, Didelphopsis + Itaboraidelphys and Stagodontidae (Figure 3). Based on this, "Eobrasiliinae" has no systematic validity.

\section{PALEOBIOGEOGRAPHIC AND PALEOECOLOGICAL IMPLICATIONS}

\section{Paleobiogeography of Stagodontidae}

The consideration of Eobrasilia coutoi as a stagodontid increases the paleobiogeographic and temporal range of this family. Previously considered extinct in North America after the Late Cretaceous-Paleogene mass extinction (around $66 \mathrm{Ma}$, Williamson et al., 2012, 2014; Wilson, 2014), the assignment of Eobrasilia to this family evidences an early 
Eocene taxon (around $52 \mathrm{Ma}$, Woodburne et al., 2014), extending the temporal range of this lineage by about 10 million years. These conclusions suggest a North American origin for Eobrasilia, with the dichotomy between Eobrasilia + Didelphodon probably proving to have occurred during the Campanian (Figure 9).

The oldest fossil records of Didelphodon are represented by Didelphodon coyi from the Judithian North American Land Mammal Age (NALMA, late Campanian) (Fox, 1981; Scott \& Fox, 2015). The discovery of an isolated tooth assigned to Eodelphis dated from the Santonian (Aquilan NALMA) from the upper part of John Henry Member of Straight Cliffs Formation, Utah, USA, indicates that the lineage of Didelphodon + Eobrasilia already existed during the Aquilan NALMA. If the dichotomy between Didelphodon and Eobrasilia happened during the early Campanian, then the lineage of the Brazilian taxon independently evolved for more than 20 million years prior to the appearance of Eobrasilia in the Itaboraí Basin during the early Eocene (Woodburne et al., 2014).

The recovered timespan for the independent evolution between Eobrasilia and Didelphodon can be considered as plausible evidence for explaining the great number of autapomorphies separating these two taxa: Eobrasilia retained the semi-procumbent lower canines and the narrow anterior part of the dentary, considered by the analysis as stagodontid plesiomorphies, while Didelphodon is apomorphic for these characters. Didelphodon is plesiomorphic in the presence of two-rooted $\mathrm{p} 3$ and not inflated dentary, which are three-rooted and inflated in Eobrasilia (autapomorphies of this species). However, despite the presence of these autapomorphies, both taxa share a great number of synapomorphies, supporting their monophyletic origin. Unfortunately, there are no confirmed metatherian fossil records during the Late Cretaceous of South
America, and Eobrasilia is restricted to the early Eocene of Itaboraí Basin. This long 'ghost-lineage' between the first fossil record of Didelphodon and Eobrasilia may explain the number of morphological differences between them.

Regarding the probable dispersal route between North and South America, the 'Aves Ridge' and adjacent Cuba were indicated as the best pathway candidates for the dispersal route between both landmasses (Bonaparte, 1984; Woodburne \& Case, 1996; Case et al., 2005; Pascual, 2006; Pascual \& Ortiz-Jaureguizar, 2007; Goin et al., 2016; Carneiro \& Oliveira, 2017). The volcanic activity during the Late Cretaceous (Pindell, 1994) associated with strong sea-level lowstands during the late Campanian (around $73 \mathrm{Ma}$ ) and the late Maastrichtian (around $66 \mathrm{Ma}$ ) (Eaton, 1993b; Haq, 2014; Carneiro \& Oliveira, 2017; Carneiro, 2017) probably allowed a sweepstakes dispersal pattern for them; with a hopping-island model as the best model for their dispersal. The marine regressions associated with intense volcanic activity probably created temporary land pathways between isolated islands until their arrival in South America.

In North America, Stagodontidae is considered as a rare group in any given local fauna (Scott \& Fox, 2015). Eobrasilia follows the group pattern, as only a partially preserved skull and a partially preserved dentary are the only elements confidently assigned to this taxon, which identifies this species as one of the rarest taxa of Itaboraí. The diagnostic and extreme adaptations of Stagodontidae undoubtedly associate their feeding habits to durophagous diets.

\section{Paleoecological implications}

In Australia, the extinct Malleodectes had its 'hammertooth' P3 associated with a durophagous diet (Arena et al., 2011; Archer et al., 2016). This conclusion can also be inferred for Eobrasilia, Gaylordia and Didelphopsis, as these species

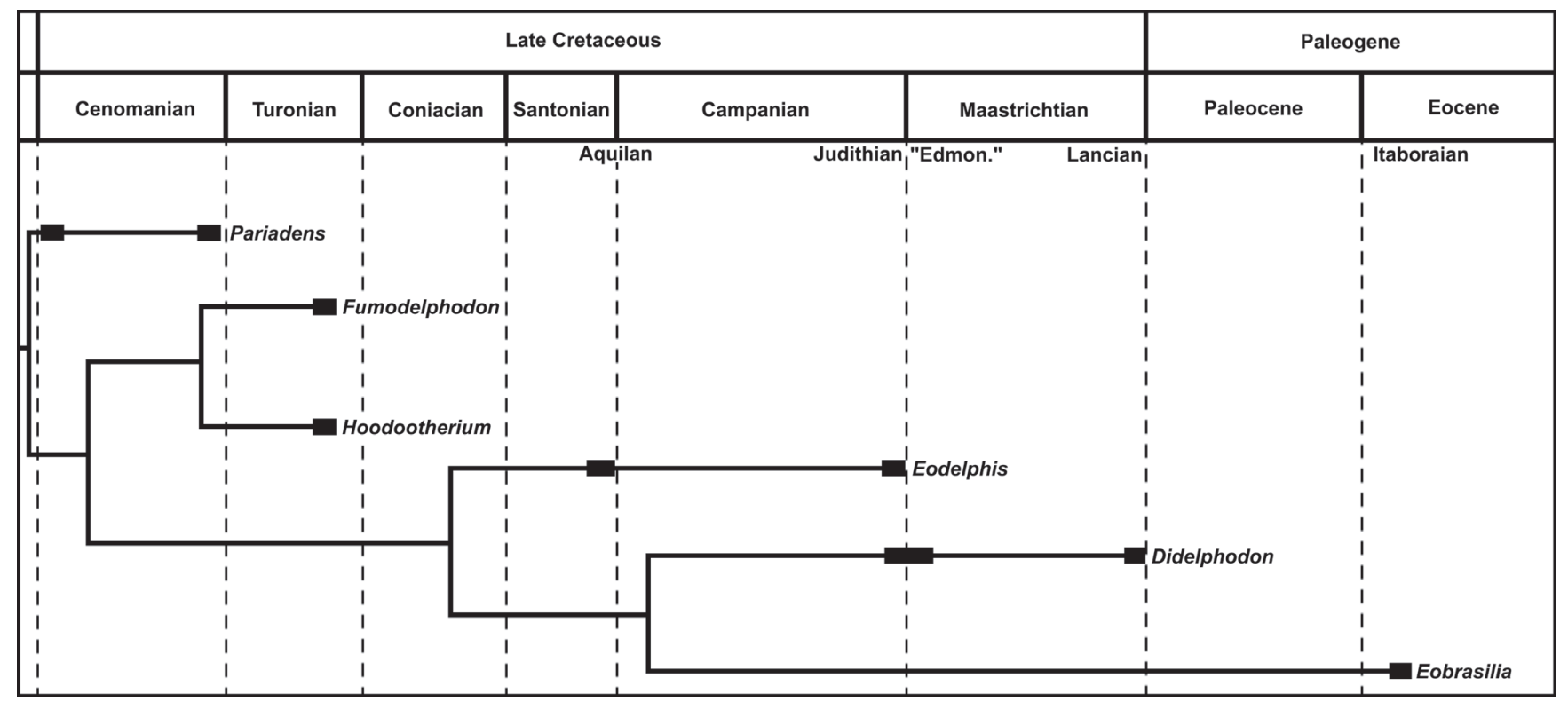

Figure 9. Temporal and geographical distribution of Stagodontidae. Phylogeny of Stagodontidae calibrated in time, based on the phylogeny present in the Figure 3. The wide bars indicate the recorded temporal range of stagodontids genera. The NALMAs and SALMAs that present stagodontids are identified. 
show similar adaptations to Malleodectes (Figure 6). Herein, the same method and explanation used by Arena et al. (2011) and Archer et al. (2016) is followed.

The tiny size of Gaylordia macrocynodonta could be an indication of the ingestion of small snail taxa, hard exoskeleton insects or even seeds, which demands durophagous adaptations. The mesiodistal compression of the upper molars, the short rostrum and the robust dentary are adaptations to increase durophagy (Thomason, 1991). The vestigial entoconid and the short talonid are adaptations for increasing carnivory or insectivory (Zimicz, 2012; Oliveira et al., 2016). The mesio-distal compression of the upper molars is also compatible with consume of soft insects or worms, as proposed for Minusculodelphis (Oliveira et al., 2016). The presence of a robust protocone, high dentary and inflated premolars in Gaylordia indicates the ingestion of harder food items (Oliveira \& Goin, 2015) (Figure 8). The tiny size and the durophagous adaptations of Gaylordia can be interpreted as indication of a specialized diet.

The results of Zimicz (2012) suggest a more frugivorous diet for Didelphopsis cabrerai, a result compatible with the global conditions during the early Eocene (Woodburne et al., 2013, 2014). The presence of inflated molars, large Stylar cusps B and D, inflated and enlarged metaconule, reduction of the paraconule and low 'U-shaped' centrocrista are more compatible with frugivory, granivory, or frugivory-durophagy (see Zimicz, 2012) (Figure 8). The presence of similar adaptations in the upper dentition of Malleodectes, including the reduction of the centrocrista, inflated Stylar cusps B and D, compressed talon and inflated premolars (see Archer et al., 2016) supports a durophagous diet for Didelphopsis. Based on these characters, Didelphopsis probably were a frugivorousdurophagous taxon.

The results of Wilson et al. (2016) suggest an omnivore diet for Didelphodon vorax; following the authors, this taxon probably consumed a range of vertebrate, plant and hard-shelled invertebrate resources but few insects, spiders and annelids (Wilson et al., 2016). The idea that this animal consumed plants is weakly supported, as the enlarged paraconid more typically occurs in carnivorous species (Zimicz, 2012). Didelphodon was more likely to be a carnivorous-durophagous taxon than an omnivore one. Eobrasilia shows evident durophagous adaptations: thickened and raised palate near the P3, incipient three-rooted p3, mesiodistally developed p3, labiolingually expanded dentary around the p3, curvature of the dentary; tiny and oblique P1 and closely spaced premolars (Simpson, 1947; Marshall, 1984). Most of these characters are also present in Malleodectes (Arena et al., 2011; Archer et al., 2016) and Didelphodon (Wilson et al., 2016). Based on available evidence, stagodontids should be considered as carnivorousdurophagous taxa, as proposed by Wilson et al. (2016) and Cohen (2017). The Turonian Fumodelphodon and the late Campanian-Maastrichtian Didelphodon independently acquired durophagous adaptations (e.g. "protocone-like" cusp in P3).
The presence of three independent metatherian lineages adapted to specialized durophagous diets in the metatherian assemblage of Itaboraí should be discussed: (i) Eobrasilia is one of the largest metatherians of the fauna and probably presented a carnivorous-durophagous diet; (ii) Didelphopsis is a relatively large species for Itaboraí standards and probably presented a frugivorous-durophagous diet; (iii) Gaylordia is among the smallest taxa of Itaboraí fauna and probably presented a insectivorous-durophagous diet. These differences in preferential food resources and size probably resulted on a low niche overlapping among these taxa, allowing their co-existence.

Similarly, to the conclusions of Arena et al. (2011) and Archer et al. (2016) for Malleodectes, the ingestion of snails should not be discarded for Eobrasilia, Didelphopsis, and Gaylordia.

Based on current fossil record, the reduction in global temperatures and floral replacement after the Early Eocene Climatic Optimum (Woodburne et al., 2013, 2014; Goin et al., 2016), and the specialized durophagous diet of Eobrasilia, Gaylordia and Didelphopsis may explain their apparently extinction after the early Eocene (Itaboraian SALMA, around $52 \mathrm{Ma}$, Woodburne et al., 2014).

\section{CONCLUSIONS}

The presence of several characters and evolutionary tendencies supports the inclusion of Eobrasilia within Stagodontidae. This result indicates a North American origin for its lineage, and a Late Cretaceous-early Paleocene dispersal event to South America. This family survived in South America until the early Eocene (Itaboraian SALMA, around $52 \mathrm{Ma}$ ).

Based on the phylogenetic analysis, Eobrasilia, Gaylordia and Didelphopsis do not constitute a monophyletic lineage. The strong divergences regarding the premolars and evolutionary tendencies imply that any attempt to group Gaylordia, Didelphopsis and Eobrasilia in a monophyletic lineage is not recommended. The diagnosis of "Eobrasiliinae" was based on homoplastic characters and ecomorphologically similar adaptations (e.g. inflated premolars), which resulted in the polyphyletic state of this taxon. As discussed here, "Eobrasiliinae" cannot be considered as a valid taxon.

\section{ACKNOWLEDGMENTS}

We thank the Universidade Federal de Pernambuco for providing the equipment and laboratories that allowed our analyses. We also would like to thank the Laboratório de Paleontologia e Paleoecologia da Sociedade de História Natural, Torres Vedras, Portugal, in which the first author is affiliated. We would like to thank R. Machado from the Museu de Ciências da Terra that gave us the permission for the study of several of these materials. L. Barbosa, curator of the Paleovertebrate collection of the Museu Nacional/UFRJ, who gave us the permission for the study of the specimens from the museum; the Centro de Microscopia Eletrônica 
de Varredura do Departamento de Invertebrados do Museu Nacional for allowing us the use of the MEV. and C.S.M.A. Messias that photograph the materials; R.L. Cifelli, Curator of Vertebrate Paleontology, Oklahoma Museum of Natural History, OK, USA, and J.E. Cohen for sending us casts of Pariadens kirklandi, which allowed the analysis of the materials assigned to this taxon; A. Maltese, curator of Rocky Mountain Dinosaur Research Center, CO, USA, for sending us pictures of Didelphodon vorax; L.P. Bergqvist, professor of the Universidade Federal do Rio de Janeiro, for her support with Itaboraí materials; and Willi Henning Society for sponsoring the construction and allowing the free use of TNT. We thank the Fundação de Amparo à Ciência e Tecnologia do Estado de Pernambuco (FACEPE) for supporting the project.

\section{REFERENCES}

Archer, M.; Hand, S.J.; Black, K.H.; Beck, R.M.D.; Arena, D.A.; Wilson, L.A.B.; Kealy, S. \& Hung, T.-t. 2016. A new family of bizarre durophagous carnivorous marsupials from Miocene deposits in the Riversleigh World Heritage Area, northwestern Queensland. Scientific Reports, 6:26911. doi:10.1038/srep26911

Arena, D.A.; Archer, M.; Godthelp, H.; Hand, S. \& Hucknull, S. 2011. Hammer-toothed 'marsupials skinks' from the Australian Cenozoic. Proceedings of the Royal Society B, 278:3529-3533. doi:10.1098/rspb.2011.0486

Beck, R.M.D. 2017. The skull of Epidolops ameghinoi from the Early Eocene Itaboraí Fauna, southeastern Brazil, and the affinities of the extinct Marsupialiform order Polydolopimorphia. Journal of Mammalian Evolution, 24:373-414. doi:10.1007/s10914016-9357-6

Bergqvist, L.P.; Mansur, K.; Rodrigues, M.A.; Rodrigues-Francisco, B.H.; Perez, R. \& Beltrão, M.C. 2009. Bacia São José de Itaboraí, RJ. Berço dos mamíferos no Brasil. In: M. Winge; C. Schobbenhaus; C.R.G. Souza; A.C.S. Fernandes; M. BerbertBorn \& E.T. Queiroz (eds.) Sítios Geológicos e Paleontológicos do Brasil, CPRM, p. 1-15.

Bi, S.; Jin, X.; Li, S. \& Du, T. 2015. A new Cretaceous metatherian mammal from Henan, China. PeerJ, 3:e896. doi:10.7717/ peerj. 896

Bonaparte, J.F. 1984. El intercambio faunístico de vertebrados continentales entre América del Sur y del Norte a fines del Cretácico. In: CONGRESO LATINOAMERICANO DE PALEONTOLOGÍA, 3, 1984. Memoria, Mexico City, UNAM, p. $438-450$.

Carneiro, L.M. 2017. A new species of Varalphadon (Mammalia, Metatheria, Sparassodonta) from the upper Cenomanian of southern Utah, North America: phylogenetic and biogeographic insights. Cretaceous Research, 84:88-96.

Carneiro, L.M. \& Oliveira, É.V. 2017. The Eocene South American metatherian Zeusdelphys complicatus is not a protodidelphid but a hatcheriform: paleobiogeographic implications. Acta Palaeontologica Polonica, 62:497-507. doi:10.4202/app.00351.2017

Carpenter, K. 2014. Where the sea meets the land - the unresolved Dakota problem in Utah. In: J.S. Maclean; R.F. Biek \& J.E. Huntoon (eds.) Geology of Utah's Far South, Salt Lake City, Utah Geological Association, p. 357-372 (Publication 43).

Case, J.A.; Goin, F.J. \& Woodburne, M.O. 2005. "South American" marsupials from the late Cretaceous of North America and the origin of marsupial cohorts. Journal of Mammalian Evolution, 12:461-494. doi:10.1007/s10914-005-7329-3
Chornogubsky, L. \& Goin, F.J. 2015. A review of the molar morphology and phylogenetic affinities of Sillustania quechuense (Metatheria, Polydolopimorphia, Sillustaniidae), from the early Paleogene of Laguna Umayo, southeastern Peru. Journal of Vertebrate Paleontology, 35:e983238. doi:10.1080/ 02724634.2015 .983238

Cifelli, R.L. 1990. Cretaceous mammals of southern Utah III. Therian mammals from the Turonian (early Late Cretaceous). Journal of Vertebrate Paleontology, 10: 332-345.

Cifelli, R.L. 2004. Marsupial mammals from the Albian-Cenomanian (Early-Late Cretaceous) boundary, Utah. Bulletin of the American Museum of Natural History, 285:62-79. doi:10.1206/00030090(2004)285<0062:C>2.0.CO;2

Cifelli, R.L \& Eaton, J.G. 1987. Marsupial from the earliest Late Cretaceous of western US. Nature, 325:520-522. doi:10.1038/325520a0

Clemens, W.A. 1966. Fossil Mammals of type Lance Formation Wyoming. Part II. Marsupialia. Berkeley, University of California, 122 p. (Publications in Geological Sciences 62).

Cohen, J.E. 2017. Earliest divergence of stagodontid (Mammalia: Marsupialiformes) feeding strategies from the Late Cretaceous (Turonian) of North America. Journal of Mammalian Evolution. doi:10.1007/s10914-017-9382-0

Eaton, J.G. 1993a. Therian mammals from the Cenomanian (Upper Cretaceous) Dakota Formation, southwestern Utah. Journal of Vertebrate Paleontology, 13:105-124. doi:10.1080/02724634. 1993.10011491

Eaton, J.G. 1993b. Marsupial dispersal. National Geographic Research \& Exploration, 9:436-443.

Eaton, J.G. 2013. Late Cretaceous mammals from Bryce Canyon National Park and Vicinity, Paunsaugunt Plateau, southwestern Utah. In: A.L. Titus \& M.A. Loewen (eds.) At the top of the Grand Staircase: the Late Cretaceous of southern Utah, Indiana University Press, p. 329-369.

Forasiepi, A.M.; Babot, M.J. \& Zimicz, N. 2014. Australohyaena antiqua (Mammalia, Metatheria, Sparassodonta), a large predator from the Late Oligocene of Patagonia. Journal of Systematic Palaeontology, 13:503-525. doi:10.1080/14772019.2014.92 6403

Forasiepi, A.M.; Sanchéz-Villagra, M.R.; Goin, F.J.; Takai, M.; Shigehara, N. \& Kay, R.F. 2006. A new species of Hathliacynidae (Mammalia, Metatheria, Sparassodonta) from the Middle Miocene of Quebrada Honda, Bolivia. Journal of Vertebrate Paleontology, 26:670-684. doi:10.1671/02724634(2006)26[670:ANSOHM]2.0.CO;2

Fox, R.C. 1981. Mammals from the Upper Cretaceous Oldman Formation, Alberta.V. Eodelphis Matthew, and the evolution of Stagodontidae (Marsupialia). Canadian Journal of Earth Sciences, 18:350-365. doi: 10.1139/e81-027

Fox, R.C. 1983. Notes on the North American Tertiary marsupials Herpetotherium and Peradectes. Canadian Journal of Earth Sciences, 20:1565-1578. doi:10.1139/e83-146

Fox, R.C \& Naylor, B.G. 1986. A new species of Didelphodon Marsh (Marsupialia) from the Upper Cretaceous of Alberta, Canada: paleobiology and phylogeny. Neues Jahrbuch fur Geologie und Paläontologie, 172:357-380.

Fox, R.C. \& Naylor, B.G. 2006. Stagodontid marsupials from the Late Cretaceous of Canada and their systematic and functional implications. Acta Palaeontologica Polonica, 51:13-36.

Goin, F.J. 2003. Early marsupial radiations in South America. In: M. Jones; C. Dickman \& M. Archer (eds.) Predators with pouches: the biology of carnivorous marsupials, Commonwealth Scientific and Industrial Research Organization, p. 30-42. 
Goin, F.J.; Candela, A.M. \& Muizon, C. 2003. The affinities of Roberthoffstetteria nationalgeographica (Marsupialia) and the origin of Polydolopine molar pattern. Journal of Vertebrate Paleontology, 23:869-876. doi:10.1671/2383-11

Goin, F.J.; Woodburne, M.O.; Zimicz, A.N.; Martin, G.M. \& Chornogubsky, L. 2016. Dispersal of vertebrates from between the Americas, Antarctica, and Australia in the Late Cretaceous and Early Cenozoic. In: P. Blondel; E. Guilyardi; J. Rabassa \& C. Horwood (eds.) A brief history of South American Metatherians, Springer, p. 77-124. doi:10.1007/978-94-017-7420-8_3

Goloboff, P.A.; Farris, J.S. \& Nixon, K.C. 2008. TNT, a free program for phylogenetic analysis. Cladistics, 24:774-786. doi:10.1111/ j.1096-0031.2008.00217.x

Haq, B.U. 2014. Cretaceous eustasy revisited. Global and Planetary Change, 113:44-58. doi:10.1016/j.gloplacha.2013.12.007

Ladevèze, S. \& Muizon, C. 2010. Evidence of early evolution of Australidelphia (Metatheria, Mammalia) in South America: phylogenetic relationships of the metatherians from the Late Palaeocene of Itaboraí (Brazil) based on teeth and petrosal bones. Zoological Journal of the Linnean Society, 159:746-784. doi:10.1111/j.1096-3642.2009.00577.x

Lofgren, D.L. 1992. Upper premolar configuration of Didelphodon vorax (Mammalia, Marsupialia, Stagodontidae). Journal of Paleontology, 66:162-164. doi:10.1017/S0022336000033576

Marshall, L.G. 1984. The lower jaw of Eobrasilia coutoi Simpson, 1947, a unique Didelphoid (not Borhyaenoid) marsupial from the Paleocene of Brazil. Journal of Paleontology, 58:173-177.

Marshall, L.G. 1987. Systematics of Itaboraian age "opossum-like" marsupials. In: M. Archer (ed.) Possums and Opossums: studies in evolution, The Royal Zoological Society of New South Wales, p. 91-160.

Marshall, L.G.; Case, J. \& Woodburne, M.O. 1990. Phylogenetic relationships of the families of marsupials. In: H.H. Genoways (ed.) Current mammalogy, Vol. 2, Plenum Press, p. 433-505.

Marshall, L.G. \& Muizon, C. 1988. The dawn of the age of mammals in South America. National Geographic Research, 4:23-55.

Matthew, W.D. 1916. A marsupial from the Belly River Cretaceous: with critical observations upon the affinities of the Cretaceous mammals. Bulletin of the American Museum of Natural History, 35:477-500.

McKenna, M.C. \& Bell, S.K. 1997. Classification of mammals above the species level. New York, Columbia University Press, 640 p.

Muizon, C. 1992. La fauna de mamiferos de Tiupampa (Paleoceno Inferior, Formacion Santa Lucia), Bolivia. In: R. Suarez-Soruco (ed.) Fosiles y facies de Bolivia - I Vertebrados, Santa Cruz, YPFB, p. 575-624 (Revista Técnica 12).

Muizon, C. \& Cifelli, R.L. 2001. A new basal "Didelphoid" (Marsupialia, Mammalia) from the early Paleocene of Tiupampa (Bolivia). Journal of Vertebrate Paleontology, 21:87-97. doi:10.1671/0272-4634(2001)021[0087:ANBDMM]2.0.CO;2

Oliveira, É.V. \& Goin, F.J. 2011. A reassessment of bunodont Metatherians from the Paleogene of Itaboraí (Brazil): systematics and age of the Itaboraian SALMA. Revista Brasileira de Paleontologia, 14:105-136. doi:10.4072/rbp.2011.2.01

Oliveira, É.V. \& Goin, F.J. 2012. Metatérios do início do Paleógeno no Brasil: diversidade e afinidades. In: N.C. Cáceres (ed.) Os marsupiais do Brasil, Editora UFMS, p. 275-310.

Oliveira, É.V. \& Goin, F.J. 2015. A new species of Gaylordia Paula Couto (Mammalia, Metatheria) from Itaboraí, Brazil. Revista Brasileira de Paleontologia, 18:97-108. doi:10.4072/ rbp.2015.1.07

Oliveira, É.V.; Zimicz, N. \& Goin, F.J. 2016. Taxonomy, affinities, and paleobiology of the tiny metatherian mammal
Minusculodelphis, from the early Eocene of South America. The Science of Nature, 103:6. doi:10.1007/s00114-015-1331-2

Pascual, R. 2006. Evolution and geography: the biogeographic history of South American land mammals. Annals of the Missouri Botanical Garden, 93:209-230. doi:10.3417/00266493(2006)93[209:EAGTBH]2.0.CO;2

Pascual, R. \& Ortiz-Jaureguizar, E. 2007. The Gondwanan and South American episodes: two major and unrelated moments in the history of the South American mammals. Journal of Mammalian Evolution, 14:75-137. doi:10.1007/s10914-007-9039-5

Paula Couto, C. 1952. Fossil mammals from the beginning of the Cenozoic in Brazil. Marsupialia: Didelphidae. American Museum Novitates, 1567:1-26.

Paula Couto, C. 1962. Didelfideos fosiles del Paleoceno de Brasil. Revista del Museo Argentino de Ciencias Naturales "Bernardino Rivadavia”, 112:135-166.

Pindell, J.L. 1994. Evolution of the Gulf of Mexico and the Caribbean. In: S.K. Donovan \& T.A. Jackson (eds.) Caribbean geology: an introduction, The University of West Indies Publishers Association, p. 13-39.

Reig, O.A.; Kirsch, J.A.W. \& Marshall, L.G. 1987. Systematic relationships of the living and Neocenozoic American "opossumlike" Marsupials (suborder Didelphimorphia), with comments on the classification of these and of the Cretaceous and Paleogene New World and European Metatherians. In: M. Archer (ed.) Possums and Opossums: studies in evolution, The Royal Zoological Society of New South Wales, p. 1-89.

Scott, C.S. \& Fox, R.C. 2015. Review of Stagodontidae (Mammalia, Marsupialia) from the Judithian (Late Cretaceous) Belly River Group of southeastern Alberta, Canada. Canadian Journal of Earth Sciences, 52:682-695. doi:10.1139/cjes-2014-0170

Simões, T.R.; Caldwell, M.W.; Palci, A. \& Nydam, R.L. 2017. Giant taxon-character matrices: quality of character constructions remains critical regardless of size. Cladistics, 33:198-219. doi:10.1111/cla.12163

Simpson, G.G. 1947. Anew Eocene marsupial from Brazil. American Museum Novitates, 1357:1-7.

Szalay, F.S. 1994. Evolutionary history of the marsupials and an analysis of osteological characters. New York, Cambridge University Press, $481 \mathrm{p}$.

Thomason, J.J. 1991. Cranial strength in relation to estimated biting forces in some mammals. Canadian Journal of Zoology, 69:2326-2333. doi:10.1139/z91-327

Vullo, R.; Gheerbrant, E.; Muizon, C. de \& Néraudeau, D. 2009. The oldest modern therian mammal from Europe and its bearing on stem marsupial paleobiogeography. Proceedings of the National Academy of Sciences of the United States of America, 106:19910-19915.

Williamson, T.E.; Brusatte, S.L.; Carr, T.D.; Weil, A. \& Standhardt, B.R. 2012. The phylogeny and evolution of CretaceousPalaeogene metatherians: cladistic analysis and description of new early Palaeocene specimens from the Nacimiento Formation, New Mexico. Journal of Systematic Palaeontology, 10:625-651. doi:10.1080/14772019.2011.631592

Williamson, T.E.; Brusatte, S.L. \& Wilson, G.P. 2014. The origin and early evolution of metatherian mammals: the Cretaceous record. ZooKeys, 465:1-76. doi:10.3897/zookeys.465.8178

Wilson, P.G. 2014. Mammalian extinction, survival, and recovery dynamics across the Cretaceous-Paleogene boundary in northeastern Montana, USA. Boulder, The Geological Society of America, p. 365-392 (Special Papers 503). doi:10.1130/2014.2503(15) 
Wilson, P.G.; Ekdale, E.G.; Hoganson, J.W.; Calede, J.J. \& Linden, A.V. 2016. A large carnivorous mammal from the Late Cretaceous and the North American origin of marsupials. Nature Communications, 7:13734. doi:10.1038/ncomms 13734

Woodburne, M.O. \& Case, J.A. 1996. Dispersal, vicariance, and the Late Cretaceous to early Tertiary land mammal biogeography from South America to Australia. Journal of Mammalian Evolution, 3:121-161. doi:10.1007/BF01454359

Woodburne, M.O.; Goin, F.J.; Bond, M.; Carlini, A.A.; Gelfo, J.N.; López, G.M.; Iglesias, A. \& Zimicz, A.N. 2013. Paleogene land mammal faunas of South America; a response to global climatic changes and indigenous floral diversity. Journal of Mammalian Evolution, 21:1-73. doi:10.1007/s10914-012-9222-1
Woodburne, M.O.; Goin, F.J.; Raigemborn, M.S.; Heizler, M.; Gelfo, J.N. \& Oliveira, É.V. 2014. Revised timing of the South American early Paleogene land mammal ages. Journal of South American Earth Sciences, 54:109-119. doi:10.1016/j. jsames.2014.05.003

Zimicz, A.N. 2012. Ecomorfología de los marsupials paleógenos de América del Sur. Facultad de Ciencias Naturales y Museo de La Plata, Universidad Nacional de la Plata, Ph.D. Thesis, 414 p.

Received in December, 2016; accepted in November, 2017. 